\title{
Chinese Public Attitudes towards, and Knowledge of, Animal Welfare
}

\author{
Francesca Carnovale ${ }^{1,2,3,+} \mathbb{D}$, Xiao Jin ${ }^{1,+}$, David Arney ${ }^{2}$, Kris Descovich ${ }^{3} \mathbb{D}^{\mathbb{D}}$, Wenliang Guo ${ }^{1}$, Binlin Shi ${ }^{1, *}$ and \\ Clive J. C. Phillips 4 (iD)
}

1 College of Animal Science, Inner Mongolia Agricultural University, 306 Zhaowuda Road, Inner Mongolia, Hohhot 010018, China; francesca.carnovale@student.emu.ee (F.C.); yaojinxiao@aliyun.com (X.J.); 18686197338@163.com (W.G.)

2 Institute of Veterinary Medicine and Animal Sciences, Estonian University of Life Sciences, Kreutzwaldi 1, 51014 Tartu, Estonia; david.arney@emu.ee

3 School of Veterinary Science, University of Queensland, Gatton, QLD 4343, Australia; k.descovich1@uq.edu.au

4 Curtin University Sustainability Policy (CUSP) Institute, Curtin University, Perth, WA 6845, Australia; clive.phillips@curtin.edu.au

* Correspondence: shibinlin@yeah.net

+ First co-authors: Francesca Carnovale and Xiao Jin.

Citation: Carnovale, F.; Jin, X.; Arney, D.; Descovich, K.; Guo, W.; Shi, B.; Phillips, C.J.C. Chinese Public Attitudes towards, and Knowledge of, Animal Welfare. Animals 2021, 11, 855. https://doi.org/10.3390/ ani11030855

Academic Editor: Marina Von Keyserlingk

Received: 29 December 2020

Accepted: 14 March 2021

Published: 17 March 2021

Publisher's Note: MDPI stays neutral with regard to jurisdictional claims in published maps and institutional affiliations.

Copyright: (c) 2021 by the authors. Licensee MDPI, Basel, Switzerland. This article is an open access article distributed under the terms and conditions of the Creative Commons Attribution (CC BY) license (https:/ / creativecommons.org/licenses/by/ $4.0 /)$.
Simple Summary: Most of our current understanding of attitudes to animals comes from studies conducted in Western countries. China, however, is the world's biggest producer of farm animals for consumption and has one of the worlds' largest populations of humans. We conducted a survey of public opinion, in order to better understand Chinese people's knowledge of animal welfare and their attitudes towards measures to adopt to improve it. Most respondents were unaware of the meaning of animal welfare, but it appears that awareness has increased in recent years. The welfare of wild animals was considered particularly important. The effects of good welfare on the taste and safety of food were highlighted and respondents were willing to pay more for food from animals raised in good welfare conditions.

Abstract: Food-producing animals make up the majority of animals that humans manage globally, and China has been a major producer and exporter of animal products since the late 1990s. The opinions of the population in China regarding animal welfare are not as well understood as those in Europe. In China, animal welfare as a societal concern is still at an early stage of development. This survey of Chinese attitudes aimed to understand consumer knowledge of and behaviour towards animal welfare, and to determine whether harnessing consumer interests may be a potential future influence on the development of high-welfare agricultural production. Most participants were not aware of the meaning of animal welfare, but the number of those that were aware was higher than reported previously. The welfare of wild animals was rated particularly important compared to other animals. The links between welfare and the taste and/or safety of food were considered to be important, and Chinese consumers reported a willingness to pay more for food from animals produced in good welfare conditions, although the quality of the food was considered more important than the animal suffering. A large majority of the respondents reported that there should be legislation protecting animals and certification of welfare on farms, that animals on farms should be provided with enjoyable experiences and that transportation times should be minimised. Furthermore, most respondents reported that animals should be stunned before slaughter. We conclude that animal welfare is of importance to the Chinese consumer, in particular because of its connection to food quality.

Keywords: animals; animal welfare; China; attitudes; knowledge; livestock; management; Europe 


\section{Introduction}

In China, as elsewhere, the nuanced differences between animal welfare and animal rights are difficult to understand for the general public [1]. This may be because these concepts were introduced into Mainland China relatively recently, in the early 1990s [1]. Animal welfare can be defined by how well an animal copes with the conditions in which it lives [2]; animal rights are predicated on the idea that the rights of non-human and human animals are, fundamentally, the same [3,4]. However, animal welfare, to a greater extent than animal rights, has attracted increased media attention in recent years [1].

In general, society is becoming more interested in the well-being of animals and our impact on them and the broader environment, at least in Europe [5]. The European Commission for Health and Food Safety [5] reported that 94\% of Europeans (including those in the UK) consider it is important to protect the welfare of farmed animals. Within the same report, it was further noted that animal welfare was more important to female respondents than male respondents, and also more important to younger respondents [5]. Food-producing animals make up the majority of animals that are managed by humans globally, and animal farming systems are accused of inefficient use of scarce resources, in particular feed, water and land [6]. Intensive animal production has continued to grow at a rapid rate over the last century [7]. The sustainability of the human-food animal relationship (which includes animal welfare) and the broader environment are likely to be at risk if, as anticipated, prices increase as a result of increasingly scarce feed, water, and land resources on which food animal producers rely $[8,9]$.

China has been a large producer and exporter of animal products since the late 1990s [10,11]. Concerns about China's record regarding disease control measures and the use of certain proscribed substances in husbandry and food processing have led to a European Union (EU) ban on the import of certain Chinese animal products, with resulting risks to the country's economy [12-15]. Chinese livestock industries have experienced a variety of major animal epidemics, such as severe acute respiratory syndrome (SARS), avian influenza, foot and mouth disease and more recently, African swine fever, all of which necessitated large numbers of animals being removed from the supply chain with considerable impact on both the livestock market and animal welfare. Improvement of animal welfare may help to prevent these disease outbreaks [16-18]. However, it is suspected that there is a fundamental lack of understanding of the importance of animal welfare among the majority of livestock stakeholders in China, leading to an absence of relevant government policies to address this [19].

Over the past 30 years, China has experienced a growth in affluence, which has been accompanied by a rise in demand for animal products [11] but, in order to improve the welfare of production animals, it is important to understand the attitudes and knowledge of the general public (as consumers) about animal welfare and, in turn, identify potential obstacles to improving the uptake of high welfare products throughout society. Improving animal welfare has direct benefits for the animals themselves, but also has significant benefits for humans who have livelihoods dependent on animal production, and for the wider community in terms of product quality and disease risk management [20].

Currently, little is known about the knowledge and attitudes of the general population towards animal welfare in China. A survey [10] in 2011 revealed that only around onethird of the Chinese public had heard about animal welfare. Of the participants, $73 \%$ believed that improving rearing conditions for swine and poultry would improve food safety of meat and eggs, and $54 \%$ expressed willingness to pay more for products from welfare-friendly operations. Platto et al. [21] asked Chinese farmers to rate several different priorities for action on farms, for example, provision of better flooring to promote hoof health or better lying areas; the improvement of animal welfare was rated third, with the most important being the farmer's own well-being [22]. In China, animal welfare, as a societal concern, is still at an early stage of development. It did not attract attention from the Chinese general public until the early years of this century [10]. Many factors are 
recognized as having an influence on the attitudes of people to animal welfare, including culture, religion and gender [23].

To date, the term "animal welfare" has no meaningful translation in the Chinese language [24,25]. A survey conducted in 2008 found that Chinese respondents had a less favourable attitude towards the importance of typical welfare issues than students in 11 European and other Asian countries [23]; however, in the same survey they had a very favourable attitude towards wildlife protection $[23,26]$. Student attitudes towards animal welfare are particularly benign in the UK, Sweden and Norway, with females giving higher ratings to animal protection than males [24,26], as well as being somewhat benign in the USA, Japan, France and Germany [27].

This survey aimed to determine the attitudes of the general public in China towards issues that impact on animals, as well as what variables influence their attitudes and their choices. As China is one of the world's major livestock-producing countries, this survey of Chinese attitudes is important from a global perspective in understanding consumer knowledge and behaviour, and whether harnessing consumer interests can have a potential future influence on the development of high-welfare agricultural production.

\section{Materials and Methods}

\subsection{Structure of the Questionnaire}

The first section of the questionnaire focused on demographic details such as age, gender, level of education, work fields, religious affiliation and place of residence (Box A1). Respondents were then asked how and if they had ever heard of animal welfare and where they had learned about it. Subsequently, they were asked if it was important for them to learn and be taught more about it, or to pay more for animal products with assured good animal welfare, and their opinion regarding the acceptance of good animal welfare by the Chinese population compared to other countries. The rest of the questionnaire was structured in four question sets with answers selected from two 5-point Likert scales. The first question set was concerned with general attitudes towards animal welfare. The second set asked which group of animals they cared most about. The third aimed to determine the reasons that they felt animals should be cared for, the fourth asked what aspects of welfare needed to be most cared for, using the Five Freedoms [28] as the basis for their choices. The survey's format and content were translated into written Chinese (Zhongwen) by the Chinese authors. The translated version was then back-translated into English for comparison with the original questionnaire and changes were made where discrepancies were evident.

\subsection{Survey Method}

The questionnaire and survey method were approved by the Human Research Ethics Committee of the University of Queensland, Australia (\#2019001811). The survey was designed by a cross-cultural research team including researchers from Inner Mongolia, China, and delivered by undergraduate students from the Inner Mongolia Agricultural University (IMAU).

Potential respondents were individually approached in public spaces (e.g., shopping centres, streets, parks, squares, markets) and by door-to-door knocking at residences, as these were likely to be most representative of all members of society. The survey responses (Box A1) were collected anonymously. A total of 217 undergraduate animal science students assisted in questionnaire dissemination and collection, with each distributing approximately ten questionnaires. Thus, a total of 2170 people were approached to complete a questionnaire between August 2019 and September 2019.

Questionnaires were delivered in 23 of the 31 directly administered provinces of the People's of Republic China, but the majority of responses were from a single province, Inner Mongolia (Figure 1). Questionnaires took approximately 10-15 min to complete. They were delivered in paper form but verbal explanations were also accepted if necessary. 


\section{Provinces of the People 's of Republic China}

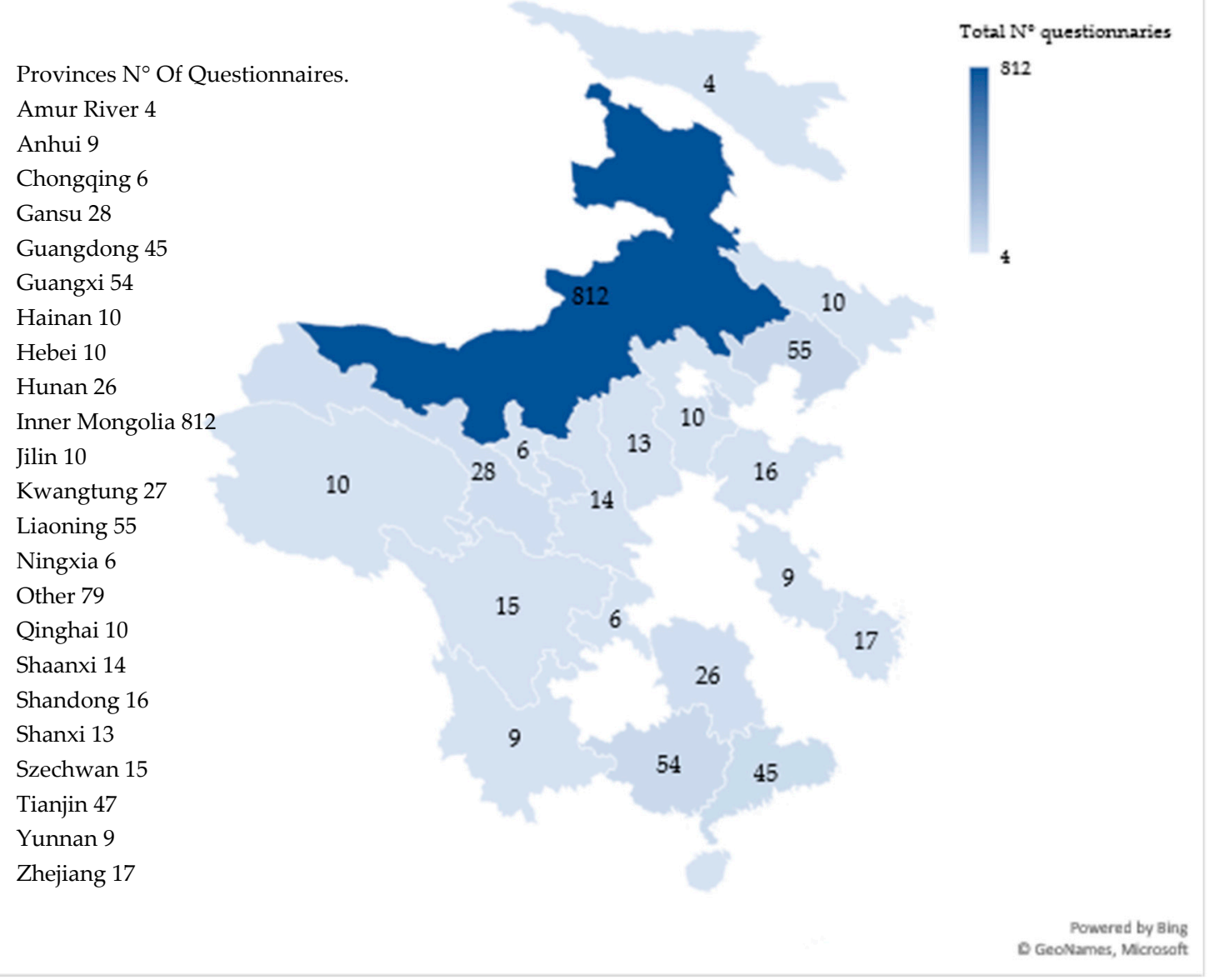

Figure 1. Map showing the collection points from the 23 provinces of the People 's of Republic China and the number of questionnaires collected (total $\mathrm{N}$ of questionnaries $=1301$ ) [29].

\subsection{Statistical Analysis}

All analyses were conducted using the statistical package Minitab (Minitab Version 18; Minitab Inc., State College, PA, USA). Descriptive statistics were generated and demographic data were analysed to check the differences between responses for all groups (Male; Female; Other; Prefer not to say etc.) using one-way ANOVAs to determine if the answers for different species were significant. Assumptions of normality were checked using the Anderson-Darling test. Non-demographic data were analysed by Ordinal Logistic Regression for ordered categorical dependent variables, and Binary Logistic Regression for binary dependent variables to predict interactions between them.

\section{Results}

A total of 1301 of the 2170 potential respondents completed the questionnaire, a response rate of $60.0 \%$. Demographic responses are shown in Table 1 . Respondents were almost equally male and female, while the national average is $3 \%$ more males than females, but were skewed towards a younger age (Table 1). About half of the participants were unaffiliated with any religion (atheist $47 \%$ ), similar to the all-China statistics (51\%). High school students (39\%) outnumbered the other final levels of education, indicating that survey respondents were educated to a higher level than the all-China levels of education. Approximately $60 \%$ of participants were employed full time, and a range of employment fields was represented. The most represented field was agriculture $(19 \%)$, which in national statistics is only $3 \%$ of those employed, and people in military work were least represented 
$(0.8 \%)$. Most participants were from urban areas $(61 \%)$ rather than rural districts or villages, while $58 \%$ of the Chinese population live in a rural area. Although most respondents were resident in the province of Inner Mongolia, there were no clear differences that could be attributed to province in our dataset.

Table 1. Demographics of respondents found in the questionnaires analysed. China statistics data from the 2018 China statistical yearbook $[30,31]$.

\begin{tabular}{|c|c|c|c|c|}
\hline Demog & c Variables & Number of Respondents & $\%$ of Survey Sample & China Statistics 2017, $\mathrm{n} \times 10^{6}$ \\
\hline \multirow{4}{*}{ Gender } & Male & 621 & 47 & Male 711 (51.17\%) \\
\hline & Female & 631 & 48 & Female $678(48.83 \%)$ \\
\hline & Other & 7 & 0.5 & $*$ \\
\hline & Prefer not to say & 39 & 3 & * \\
\hline \multirow{6}{*}{ Age } & $18-24$ & 434 & 33 & $132(14 \%)$ \\
\hline & $25-34$ & 339 & 26 & $189(20 \%)$ \\
\hline & $35-44$ & 253 & 19 & $170(18 \%)$ \\
\hline & $45-54$ & 177 & 13 & $202(21 \%)$ \\
\hline & $55-64$ & 65 & 5 & $127(13 \%)$ \\
\hline & $>65$ & 27 & 2 & $130(14 \%)$ \\
\hline \multirow{9}{*}{ Religion } & Chinese folk & 213 & 16 & $304(21 \%)$ \\
\hline & Atheist & 611 & 47 & $720(51 \%)$ \\
\hline & Buddhism & 132 & 10 & $254(18 \%)$ \\
\hline & Muslim & 29 & 2 & $28(2 \%)$ \\
\hline & Christians & 23 & 1 & $72(5 \%)$ \\
\hline & Daoism & 26 & 2 & $*$ \\
\hline & Confucianism & 25 & 1 & * \\
\hline & Prefer not to say & 128 & 9 & * \\
\hline & Other & 106 & 720 & $9(<1 \%)$ \\
\hline \multirow{6}{*}{ Education } & $\begin{array}{c}\text { Elementary } \\
\text { school or below }\end{array}$ & 131 & 10 & $730(55 \%)$ \\
\hline & Technical college & 146 & 11 & $*$ \\
\hline & Middle school & 160 & 12 & $286(21 \%)$ \\
\hline & High school & 507 & 39 & $321(24 \%)$ \\
\hline & $\begin{array}{c}\text { University } \\
\text { undergraduate }\end{array}$ & 270 & 20 & $0.8(<1 \%)$ \\
\hline & $\begin{array}{c}\text { University } \\
\text { postgraduate }\end{array}$ & 86 & 6 & $0.5(<1 \%)$ \\
\hline \multirow{2}{*}{ Employed } & Yes & 781 & 60 & \multirow{2}{*}{776} \\
\hline & No & 504 & 39 & \\
\hline \multirow{14}{*}{ Work field } & Administration & 113 & 9 & * \\
\hline & Agriculture & 239 & 19 & $2.25(3 \%)$ \\
\hline & Arts & 44 & 3 & $*$ \\
\hline & Construction & 94 & 7 & $26(33 \%)$ \\
\hline & Education & 121 & 9 & $17(22 \%)$ \\
\hline & Finance & 39 & 3 & $6.88(9 \%)$ \\
\hline & Government & 54 & 4 & $*$ \\
\hline & Health & 78 & 6 & $8.97(11 \%)$ \\
\hline & Mining & 22 & 1 & $4.55(6 \%)$ \\
\hline & Military & 11 & 0.8 & $*$ \\
\hline & Retail/Sales & 101 & 8 & $8.42(11 \%)$ \\
\hline & Science & 23 & 1 & $4.20(5 \%)$ \\
\hline & Technology & 65 & 5 & $*$ \\
\hline & Other & 251 & 20 & * \\
\hline \multirow{4}{*}{ Dwelling } & Rural & 171 & 13 & $813(58.5 \%)$ \\
\hline & Village & 321 & 24 & $*$ \\
\hline & Urban & 793 & 61 & $576(41.45 \%)$ \\
\hline & Other & 14 & 1 & $*$ \\
\hline
\end{tabular}




\subsection{Respondents' Knowledge}

The responses to attitudinal questions on animal welfare are shown in Table 2. Almost half of the respondents $(47 \%)$ had never heard of the term 'animal welfare'. However, a similar percentage of respondents stated that they live in harmony with animals (43\%) and that it is very important to care for animals (53\%). About a quarter of respondents stated that animal care should probably not, or definitely not, be taught in schools and only $2 \%$ had learned about caring for animals in formal study. Most respondents indicated that they had learned about the care of animals from family and friends or from social media (Table 3).

Table 2. Respondents' attitudes towards animal welfare in China.

\begin{tabular}{|c|c|c|c|}
\hline \multicolumn{2}{|c|}{ Questions and Response Options } & \multirow{2}{*}{$\begin{array}{c}\text { Number of Respondents } \\
99\end{array}$} & \multirow{2}{*}{$\frac{\% \text { of Survey Sample }}{7}$} \\
\hline \multirow{4}{*}{$\begin{array}{c}\text { Have you heard of the phrase "animal } \\
\text { welfare"? }\end{array}$} & Not sure & & \\
\hline & Never & 608 & 47 \\
\hline & A few times & 453 & 35 \\
\hline & Many times & 128 & 9 \\
\hline \multirow{5}{*}{ Do you live in harmony with animals? } & Not at all & 70 & 5 \\
\hline & Slightly & 247 & 19 \\
\hline & Moderately & 411 & 31 \\
\hline & Very much & 312 & 24 \\
\hline & To a great extent & 256 & 19 \\
\hline \multirow{5}{*}{$\begin{array}{l}\text { How important is caring for animals to you as } \\
\text { a person? }\end{array}$} & Not at all & 47 & 3 \\
\hline & Slightly & 176 & 13 \\
\hline & Moderately & 380 & 29 \\
\hline & Very & 471 & 36 \\
\hline & Extremely & 221 & 17 \\
\hline \multirow{5}{*}{$\begin{array}{l}\text { Do you think that animal care should be taught } \\
\text { in schools? }\end{array}$} & Definitely not & 90 & 6 \\
\hline & Probably not & 238 & 18 \\
\hline & Possibly & 477 & 36 \\
\hline & Probably & 308 & 23 \\
\hline & Definitely & 185 & 14 \\
\hline \multirow{2}{*}{$\begin{array}{l}\text { Would you be willing to pay more for products } \\
\text { from animals that are better cared for? }\end{array}$} & Yes & 757 & 58 \\
\hline & No & 532 & 41 \\
\hline \multirow{6}{*}{$\begin{array}{l}\text { If yes, how much more would you be willing to } \\
\text { pay for a product from an animal very well } \\
\text { cared for compared with the standard product? }\end{array}$} & $5 \%$ & 423 & 35 \\
\hline & $10 \%$ & 328 & 27 \\
\hline & $20 \%$ & 262 & 21 \\
\hline & $50 \%$ & 115 & 9 \\
\hline & $100 \%$ & 36 & 2 \\
\hline & $>100 \%$ & 41 & 3 \\
\hline \multirow{5}{*}{$\begin{array}{c}\text { What do you think is the current standard of } \\
\text { animal care in China? }\end{array}$} & Very poor & 128 & 10 \\
\hline & Poor & 557 & 43 \\
\hline & Satisfactory & 383 & 30 \\
\hline & Good & 164 & 12 \\
\hline & Very good & 40 & 3 \\
\hline \multirow{5}{*}{$\begin{array}{l}\text { How do you think the standard of animal care } \\
\text { in China compares to other countries? }\end{array}$} & Much worse & 263 & 20 \\
\hline & Somewhat worse & 473 & 36 \\
\hline & About the same & 428 & 33 \\
\hline & Better & 91 & 7 \\
\hline & Much Better & 42 & 3 \\
\hline \multirow{8}{*}{$\begin{array}{l}\text { Who do you think is most responsible for the } \\
\text { adequate care of animals? }\end{array}$} & Government & 100 & 8 \\
\hline & Animal Protection Organizations & 157 & 13 \\
\hline & Farmers & 18 & 1 \\
\hline & All of society & 516 & 44 \\
\hline & People who like animals & 123 & 10 \\
\hline & People who own animals & 167 & 14 \\
\hline & Companies that use animals & 23 & 2 \\
\hline & Other & 48 & 4 \\
\hline
\end{tabular}


Table 3. Origin of respondent's awareness of caring for animals.

\begin{tabular}{|c|c|c|c|}
\hline $\begin{array}{l}\text { Did the Following Help You to Learn } \\
\text { about Caring for Animals? }\end{array}$ & & Number of Respondents & $\%$ of Survey Sample \\
\hline \multirow{2}{*}{ Formal study } & Yes & 29 & 2 \\
\hline & No & 1273 & 97 \\
\hline \multirow{2}{*}{ Family and friends } & Yes & 459 & 35 \\
\hline & No & 845 & 64 \\
\hline \multirow{2}{*}{ Media } & Yes & 252 & 19 \\
\hline & No & 1050 & 80 \\
\hline \multirow{2}{*}{ Business } & Yes & 57 & 4 \\
\hline & No & 1245 & 95 \\
\hline \multirow{2}{*}{ My job } & Yes & 110 & 19 \\
\hline & No & 1192 & 80 \\
\hline \multirow[b]{2}{*}{ Government } & Yes & 46 & 3 \\
\hline & No & 1256 & 96 \\
\hline \multirow{2}{*}{ Animal protection organization } & Yes & 178 & 13 \\
\hline & No & 1124 & 86 \\
\hline \multirow{2}{*}{ Social media } & Yes & 359 & 27 \\
\hline & No & 943 & 72 \\
\hline \multirow{2}{*}{ Farmer } & Yes & 84 & 6 \\
\hline & No & 1218 & 93 \\
\hline \multirow{2}{*}{ Have not learnt } & Yes & 106 & 8 \\
\hline & No & 1196 & 91 \\
\hline \multirow{2}{*}{ Other } & Yes & 22 & 1 \\
\hline & No & 1280 & 98 \\
\hline
\end{tabular}

Most respondents (58\%) reported that they would be willing to pay more for animal products if the animals had been well cared for, and more than $60 \%$ of these would be willing to pay more than an additional $5 \%$ in price (Table 2). More than half of the respondents thought that the current standard of care for animals in China is poor or very poor. A third stated that the standard of animal care in China was similar to other countries, but only $10 \%$ responded that it was better or much better. The responsibility for the care of animals was indicated by most respondents to lie with society as a whole $(44 \%)$, and the number of respondents suggesting it to be mainly the responsibility of farmers was very small (1\%).

\subsection{Attitudes towards Different Animal Taxa}

In order to investigate the relative attitudes towards different species, respondents were asked how important it is that different animal groups are cared for (Figure 2 and Table A1). More than $80 \%$ thought it was somewhat or very important that mammals, reptiles and birds are well cared for and over 68\% responded similarly for insects (Figure 2). In terms of different animal use contexts, the care of pet animals, experimental animals, agricultural animals, stray animals and wildlife were all reported to be somewhat or very important, by over $83 \%$ of respondents (Figure 2). Very few respondents answered that being well cared for was 'not at all important' for any of the animal groups listed. Respondents considered that it was more important that mammals should be cared for than other animal groups (between $p<0.03$ and $p<0.0001$ ) (Table A2). 

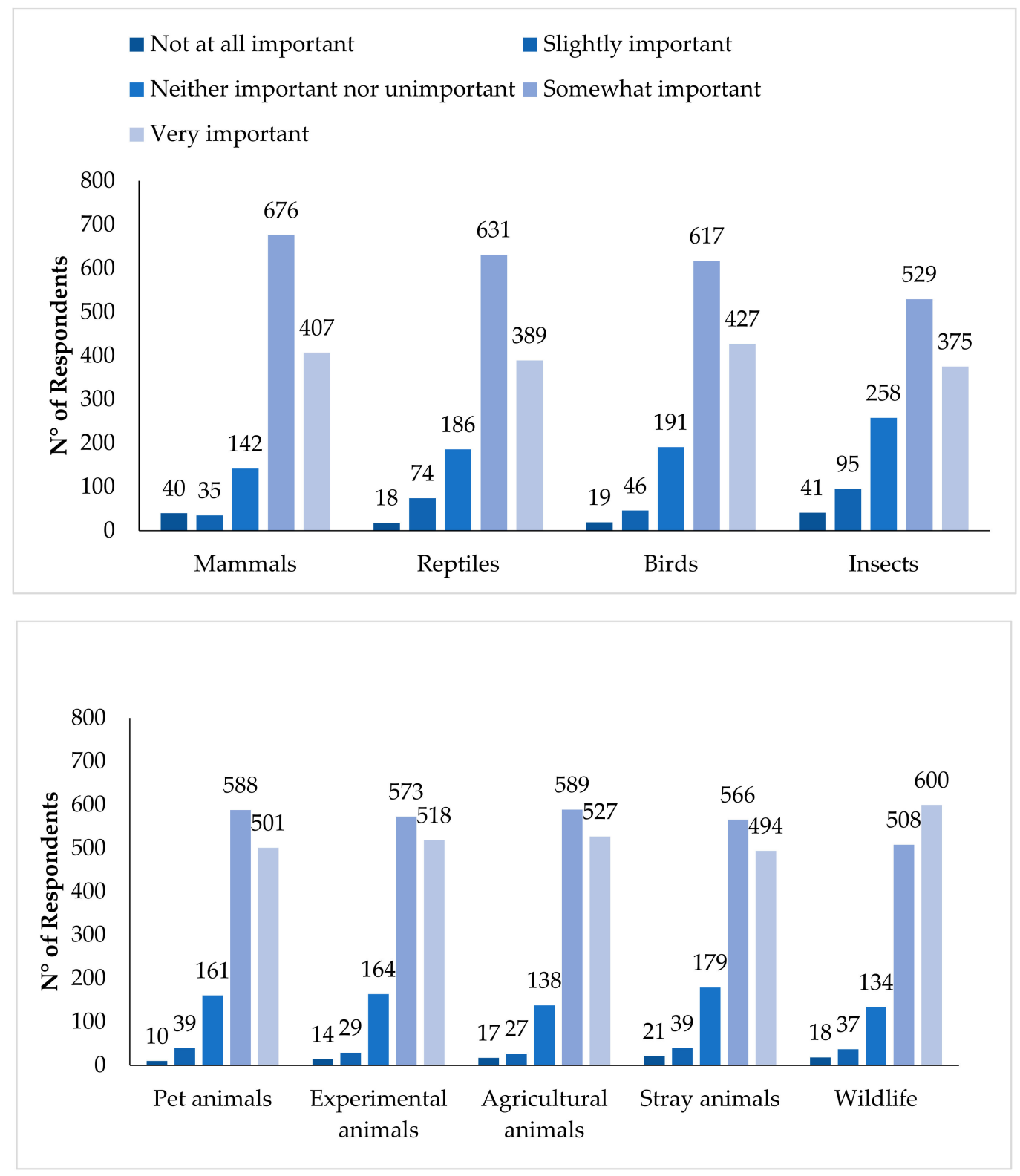

Figure 2. The relative perceptions of attitudes towards animal taxa and different animal-use groups in China, on a scale from "Not important" to "Very important" that they are well cared for.

Most respondents ( $>1000$ ) (Table 4) agreed or strongly agreed that reasons to care for animals were for food safety $(85 \%)$ and for the sake of the environment $(85 \%)$, and these were more strongly supported than the other options $(p<0.05-0.0001)$ : (Table A3 Similarly, most $(>900)$ respondents agreed or strongly agreed that caring for animals makes them feel good $(75 \%)$, which was more strongly supported than "for the sake of animals" $(69 \%)$ and "because my religion tells me so" (59\%) (between $p<0.005$ and $p<0.0001)$ (Table 4). Other differences, and their probabilities, are listed in Table A3.

\subsection{Attitudes towards Animal Welfare and Procedures Performed on Animals}

Importance ratings for the evaluated welfare assessment criteria are shown in Table 5. For each criterion the majority of respondents (over $80 \%$ in all cases) reported that they strongly supported it, with physical fitness being the most important. Differences between respondents' answers both within and between criteria are listed in Table A4.

Responses regarding animal procedures are listed in Table 6. A large majority of respondents agreed or strongly agreed that there should be legislation protecting ani- 
mals, that farms should be certified by animal protection organisations, and that such organisations are important in ensuring these animals' care. Over half of the respondents considered management mutilations, such as castration, ear tagging and tail docking, to be acceptable. Minimisation of animal transportation time was thought to be important by $79 \%$ of respondents. A similar number agreed or strongly agreed that animals should be provided with enjoyable experiences on farms $(82 \%)$. However, $70 \%$ of respondents agreed that it is acceptable for animals to suffer if the quality of the product is good enough, and over a third (44\%) if the price of the product is low enough. However, a large majority of respondents thought that animals should be stunned before slaughter and that animals should be dead before being cooked.

Table 4. Reasons for caring for animals, listed in declining order of agreement.

\begin{tabular}{|c|c|c|c|}
\hline \multicolumn{2}{|c|}{$\begin{array}{c}\text { Indicate How Strongly You Agree or Disagree with the } \\
\text { Following Reasons }\end{array}$} & \multirow{2}{*}{$\begin{array}{c}\text { Number of Respondents } \\
42\end{array}$} & \multirow{2}{*}{$\frac{\text { \% of Survey Sample }}{3}$} \\
\hline \multirow{5}{*}{ It is important for food safety } & Strongly disagree & & \\
\hline & Disagree & 56 & 4 \\
\hline & Neither agree nor disagree & 97 & 7 \\
\hline & Agree & 673 & 51 \\
\hline & Strongly agree & 433 & 33 \\
\hline \multirow{5}{*}{$\begin{array}{l}\text { It is important for the } \\
\text { environment }\end{array}$} & Strongly disagree & 13 & 1 \\
\hline & Disagree & 51 & 3 \\
\hline & Neither agree nor disagree & 131 & 10 \\
\hline & Agree & 628 & 48 \\
\hline & Strongly agree & 477 & 36 \\
\hline \multirow{5}{*}{$\begin{array}{l}\text { To improve product quality or } \\
\text { taste }\end{array}$} & Strongly disagree & 20 & 1 \\
\hline & Disagree & 34 & 2 \\
\hline & Neither agree nor disagree & 156 & 12 \\
\hline & Agree & 599 & 46 \\
\hline & Strongly agree & 491 & 37 \\
\hline \multirow{5}{*}{ It is good for human health } & Strongly disagree & 19 & 1 \\
\hline & Disagree & 61 & 4 \\
\hline & Neither agree nor disagree & 209 & 16 \\
\hline & Agree & 593 & 45 \\
\hline & Strongly agree & 419 & 32 \\
\hline \multirow{5}{*}{$\begin{array}{l}\text { To improve profit from } \\
\text { animals }\end{array}$} & Strongly disagree & 55 & 4 \\
\hline & Disagree & 76 & 5 \\
\hline & Neither agree nor disagree & 178 & 13 \\
\hline & Agree & 576 & 44 \\
\hline & Strongly agree & 416 & 31 \\
\hline \multirow{5}{*}{ It makes me feel good } & Strongly disagree & 14 & 1 \\
\hline & Disagree & 63 & 4 \\
\hline & Neither agree nor disagree & 237 & 18 \\
\hline & Agree & 600 & 46 \\
\hline & Strongly agree & 387 & 29 \\
\hline \multirow{5}{*}{ For the sake of the animals } & Strongly disagree & 50 & 3 \\
\hline & Disagree & 117 & 8 \\
\hline & Neither agree nor disagree & 225 & 17 \\
\hline & Agree & 514 & 39 \\
\hline & Strongly agree & 395 & 30 \\
\hline \multirow{5}{*}{ My religion tells me to } & Strongly disagree & 51 & 3 \\
\hline & Disagree & 113 & 8 \\
\hline & Neither agree nor disagree & 361 & 27 \\
\hline & Agree & 463 & 35 \\
\hline & Strongly agree & 313 & 24 \\
\hline
\end{tabular}


Table 5. Attitudes towards animal care based on animal welfare evaluation criteria, in declining order of importance.

\begin{tabular}{|c|c|c|c|}
\hline \multicolumn{2}{|c|}{ How Important are the Following Conditions in Animal Care? } & \multirow{2}{*}{ Number of Respondents } & \multirow{2}{*}{$\frac{\text { \% of Survey Sample }}{0.4}$} \\
\hline \multirow{5}{*}{ Physical fitness } & Not at all important & & \\
\hline & Slightly important & 25 & 1 \\
\hline & Neither important nor unimportant & 95 & 7 \\
\hline & Somewhat important & 576 & 44 \\
\hline & Very important & 598 & 46 \\
\hline \multirow{5}{*}{ Absence of disease or injury } & Not at all important & 5 & 0.3 \\
\hline & Slightly important & 23 & 1 \\
\hline & Neither important nor unimportant & 97 & 7 \\
\hline & Somewhat important & 611 & 46 \\
\hline & Very important & 565 & 43 \\
\hline \multirow{5}{*}{ A comfortable environment } & Not at all important & 10 & 0.7 \\
\hline & Slightly important & 24 & 1 \\
\hline & Neither important nor unimportant & 131 & 10 \\
\hline & Somewhat important & 613 & 47 \\
\hline & Very important & 521 & 40 \\
\hline \multirow{5}{*}{ Species-relevant nutrition } & Not at all important & 37 & 2 \\
\hline & Slightly important & 32 & 2 \\
\hline & Neither important nor unimportant & 96 & 7 \\
\hline & Somewhat important & 661 & 50 \\
\hline & Very important & 475 & 36 \\
\hline \multirow{5}{*}{ Access to drinking water } & Not at all important & 8 & 0.6 \\
\hline & Slightly important & 50 & 3 \\
\hline & Neither important nor unimportant & 116 & 8 \\
\hline & Somewhat important & 638 & 49 \\
\hline & Very important & 487 & 37 \\
\hline \multirow{5}{*}{ Space } & Not at all important & 4 & 0.3 \\
\hline & Slightly important & 39 & 3 \\
\hline & Neither important nor unimportant & 116 & 8 \\
\hline & Somewhat important & 596 & 45 \\
\hline & Very important & 545 & 41 \\
\hline \multirow{5}{*}{ Absence of fear or distress } & Not at all important & 14 & 1 \\
\hline & Slightly important & 40 & 3 \\
\hline & Neither important nor unimportant & 124 & 9 \\
\hline & Somewhat important & 596 & 45 \\
\hline & Very important & 527 & 40 \\
\hline \multirow{5}{*}{ Absence of pain } & Not at all important & 10 & 0.7 \\
\hline & Slightly important & 42 & 3 \\
\hline & Neither important nor unimportant & 129 & 9 \\
\hline & Somewhat important & 544 & 41 \\
\hline & Very important & 575 & 44 \\
\hline \multirow{5}{*}{$\begin{array}{l}\text { Control over their } \\
\text { environment }\end{array}$} & Not at all important & 15 & 1 \\
\hline & Slightly important & 40 & 3 \\
\hline & Neither important nor unimportant & 149 & 11 \\
\hline & Somewhat important & 555 & 42 \\
\hline & Very important & 542 & 41 \\
\hline \multirow{5}{*}{$\begin{array}{l}\text { Opportunity to perform } \\
\text { natural behaviours }\end{array}$} & Not at all important & 8 & 0.6 \\
\hline & Slightly important & 42 & 3 \\
\hline & Neither important nor unimportant & 181 & 13 \\
\hline & Somewhat important & 564 & 43 \\
\hline & Very important & 505 & 38 \\
\hline
\end{tabular}


Table 6. Attitudes towards strategies for the management of animals.

\begin{tabular}{|c|c|c|c|}
\hline \multicolumn{2}{|c|}{ Indicate Your Level of Agreement with the Following Statements } & $\begin{array}{c}\text { Number of Respondents } \\
62\end{array}$ & $\frac{\text { \% of Survey Sample }}{4}$ \\
\hline $\begin{array}{l}\text { Farms with animals should be } \\
\text { certified by animal protection } \\
\text { organizations }\end{array}$ & $\begin{array}{c}\text { Strongly disagree } \\
\text { Disagree } \\
\text { Neither agree nor disagree } \\
\text { Agree } \\
\text { Strongly agree }\end{array}$ & $\begin{array}{c}62 \\
39 \\
133 \\
660 \\
406\end{array}$ & $\begin{array}{c}4 \\
3 \\
10 \\
50 \\
31\end{array}$ \\
\hline $\begin{array}{l}\text { Procedures performed on } \\
\text { animals such as ear tags, } \\
\text { castrations and tail docking } \\
\text { are acceptable for } \\
\text { management }\end{array}$ & $\begin{array}{c}\text { Strongly disagree } \\
\text { Disagree } \\
\text { Neither agree nor disagree } \\
\text { Agree } \\
\text { Strongly agree }\end{array}$ & $\begin{array}{l}109 \\
245 \\
180 \\
521 \\
246\end{array}$ & $\begin{array}{c}8 \\
18 \\
13 \\
40 \\
18\end{array}$ \\
\hline $\begin{array}{l}\text { Transportation time of live } \\
\text { animals should be minimized }\end{array}$ & $\begin{array}{c}\text { Strongly disagree } \\
\text { Disagree } \\
\text { Neither agree nor disagree } \\
\text { Agree } \\
\text { Strongly agree }\end{array}$ & $\begin{array}{l}16 \\
31 \\
211 \\
641 \\
400\end{array}$ & $\begin{array}{c}1 \\
2 \\
16 \\
49 \\
30\end{array}$ \\
\hline $\begin{array}{c}\text { Animals on farms should be } \\
\text { provided with enjoyable } \\
\text { experiences }\end{array}$ & $\begin{array}{c}\text { Strongly disagree } \\
\text { Disagree } \\
\text { Neither agree nor disagree } \\
\text { Agree } \\
\text { Strongly agree }\end{array}$ & $\begin{array}{c}19 \\
31 \\
175 \\
642 \\
434 \\
\end{array}$ & $\begin{array}{c}1 \\
2 \\
13 \\
49 \\
33 \\
\end{array}$ \\
\hline $\begin{array}{c}\text { It is OK to buy products of } \\
\text { animals that have suffered if } \\
\text { the product quality is good } \\
\text { enough }\end{array}$ & $\begin{array}{c}\text { Strongly disagree } \\
\text { Disagree } \\
\text { Neither agree nor disagree } \\
\text { Agree } \\
\text { Strongly agree }\end{array}$ & $\begin{array}{l}178 \\
250 \\
223 \\
409 \\
241\end{array}$ & $\begin{array}{c}2 \\
6 \\
19 \\
44 \\
26\end{array}$ \\
\hline $\begin{array}{l}\text { It is OK to buy products of } \\
\text { animals that have suffered if } \\
\text { the price is low enough }\end{array}$ & $\begin{array}{c}\text { Strongly disagree } \\
\text { Disagree } \\
\text { Neither agree nor disagree } \\
\text { Agree } \\
\text { Strongly agree }\end{array}$ & $\begin{array}{l}187 \\
277 \\
244 \\
247 \\
245\end{array}$ & $\begin{array}{l}14 \\
21 \\
18 \\
26 \\
18\end{array}$ \\
\hline $\begin{array}{l}\text { Animals should be } \\
\text { unconscious (stunned) before } \\
\text { they are killed }\end{array}$ & $\begin{array}{c}\text { Strongly disagree } \\
\text { Disagree } \\
\text { Neither agree nor disagree } \\
\text { Agree } \\
\text { Strongly agree }\end{array}$ & $\begin{array}{c}34 \\
89 \\
250 \\
582 \\
346\end{array}$ & $\begin{array}{c}2 \\
6 \\
19 \\
44 \\
26\end{array}$ \\
\hline $\begin{array}{l}\text { Animals should be killed } \\
\text { before being cooked }\end{array}$ & $\begin{array}{c}\text { Strongly disagree } \\
\text { Disagree } \\
\text { Neither agree nor disagree } \\
\text { Agree } \\
\text { Strongly agree }\end{array}$ & $\begin{array}{c}30 \\
48 \\
197 \\
575 \\
450\end{array}$ & $\begin{array}{c}2 \\
3 \\
15 \\
44 \\
34\end{array}$ \\
\hline $\begin{array}{l}\text { It is important to have } \\
\text { legislation that ensures animal } \\
\text { care is adequate }\end{array}$ & $\begin{array}{c}\text { Strongly disagree } \\
\text { Disagree } \\
\text { Neither agree nor disagree } \\
\text { Agree } \\
\text { Strongly agree }\end{array}$ & $\begin{array}{c}21 \\
25 \\
126 \\
557 \\
571\end{array}$ & $\begin{array}{c}1 \\
1 \\
9 \\
42 \\
43\end{array}$ \\
\hline $\begin{array}{l}\text { Animal protection } \\
\text { organizations are important in } \\
\text { ensuring animals are } \\
\text { adequately cared for }\end{array}$ & $\begin{array}{c}\text { Strongly disagree } \\
\text { Disagree } \\
\text { Neither agree nor disagree } \\
\text { Agree } \\
\text { Strongly agree }\end{array}$ & $\begin{array}{c}19 \\
31 \\
119 \\
537 \\
594\end{array}$ & $\begin{array}{c}1 \\
2 \\
9 \\
41 \\
45\end{array}$ \\
\hline
\end{tabular}




\section{Discussion}

The survey we conducted suggests that there has been an improvement in the perception of animal welfare in China since a 2008 survey of students found that China had the lowest acceptance rating for animal welfare issues of 13 Eurasian countries [23,26]. However, that survey also found that there was considerable support for wildlife protection within China [26].

\subsection{Respondents' Knowledge about Animal Welfare}

Almost half of the respondents had never heard of the term "animal welfare," which does not necessarily mean that Chinese people do not care about the well-being of animals but Phillips et al. (2012) [26] showed that respondents in a sample of European countries generally had greater concern for the welfare of animals than those in a sample of Asian countries, including China. The Chinese government considers it necessary to adopt intensive rearing in order to meet the growing demand for the products of livestock [24,32-34]. As has also been shown in other studies, respondents were very sensitive about killing animals and all practices used on the farm [10]. Respondents mostly knew about animal care and welfare from family and friends, and also from the media. This indicates that reporting in the media may have improved since You et al. (2014) [10] claimed that discussion of animal welfare by the Chinese media was poor at that time. Respondents in the current study mostly felt that they lived in harmony with animals, which may be a reflection of the provinces where the survey was conducted, where agriculture in the economy and animal production are important. Current profession may be more pivotal than educational background in approaches to welfare measures and criteria [9].

Most respondents agreed that it was either very or extremely important to care for animals. Among other reasons, food safety was a common reason for this, as has been found in other studies [5]. Three-quarters of the respondents said that animal welfare should be taught in schools, and likewise Europeans (87\%) consider that this is a good way to influence the attitudes of the younger generation towards animals [35,36]. As the survey was distributed by students it is possible that a disproportionate number of the respondents were from high school and university, and educational background influenced views on animal welfare aspects, as has also been shown in other studies [10]. The findings may therefore be skewed towards the perceptions of the younger generation.

The respondents thought that the current standard of care for animals in China is poor or very poor, acknowledging perhaps that there is difficulty in applying high welfare animal husbandry for the production of a large amount of animal products [37]. According to research carried out on meat consumption in China, future spending on meat is expected to increase [38]. This nutritional transition is a response to changes in lifestyle and dietary patterns driven by urbanization, globalization and economic growth, and their resulting impacts on nutrition and health outcomes [39]. But there remains significant diversity of diets around the world, reflecting diversity in food production landscapes and ecosystems, socio-economic conditions, cultures and beliefs. Studies of food systems adapted to their local context, and of the associated traditional knowledge built up over millennia, can provide new insights and pathways towards more sustainable food systems [40]. Most respondents said that they would be willing to pay more for high welfare standard products, which was not found in a previous survey in China [10]. If true, this could drive improvements in good practices on livestock farms; $58 \%$ of UK customers believe that by paying more for higher welfare products they can influence the welfare conditions of the animals [41]. In another European survey, Bozzo et al. [42] showed that $58.4 \%$ of the persons interviewed would pay $20 \%$ more than normal for high welfare products, while in this study $35 \%$ of respondents were prepared to pay more than $10 \%$ extra, which was most likely due to the perceived improved taste of the animal-derived product and effects on the environment. The European Commission for Health and Food Safety [5] reported that a sample population from 15 Member States of the EU considered that animal welfare contributes to a better-quality animal product. 


\subsection{Chinese Attitudes towards Animal Taxa and Reasons for Care of the Animals}

The Chinese population appears concerned about all types of animals, since none of the species listed in the questionnaire were identified by many as unimportant. Davey and $\mathrm{Wu}$ [43], reported that Chinese students were concerned about the use of animals for research, which was also found in our study. Interestingly in the current study, wild animals had the highest amount of support from participants: $46 \%$ for very important and $39 \%$ for somewhat important. This importance attached to wildlife confirms an earlier study in which Chinese respondents did not care much about animal welfare generally [26] but were very concerned about wildlife protection $[23,44]$. This was further borne out by the findings of Phillips et al. (2012) [26] that of a range of countries, Chinese respondents scored lowest for animal welfare generally, but highest for the importance of welfare issues among wild animals. That this strength of comparative interest in the welfare of wild animals may have a cultural basis is worthy of further consideration and investigation. It may also be due to an increase in information regarding diseases that can be transmitted from wild animals, which up until recently few people were aware of [45]. Consumers consider farm animal welfare as an attribute of the food quality concept, with more importance given to this than to other attributes $[46,47]$. There is evidence from this survey that the Chinese population has responded positively to understanding the reasons why animals should care for, and how animal welfare affects other aspects, such as food safety, in China. The disease burden and use of antibiotics in farm animals is taken very seriously in China by government and could be considered a platform from which to advocate improvements to animal welfare [48].

\subsection{Chinese Attitudes towards Animal Welfare and Procedures Performed on Animals}

China has not yet enacted animal welfare legislation and the reason for this may be in part due to the perceived lack of animal welfare information in the country [1]. In 2005, the National People's Congress voted on the Animal Husbandry Law of the People's Republic of China, but the omission of the term 'animal welfare' reflects the fact that much of the public and many legislators are of the opinion that animal welfare cannot become a topic codified in the law [49]. The culture in a country can affect perceptions of animal sentience, which according to several studies $[5,26,49]$ will then correlate with the perception of whether practices involving the animal species are considered cruel or not.

The majority of participants in our study considered the absence of injury to be somewhat important. In the EU, inflicting pain and injury are thought to be so wellcontrolled that people assume that they must be necessary otherwise they would not be allowed [26]. In this case the European respondents may be more trusting of animal production practices and animal welfare than their Chinese peers.

The respondents generally agreed that animals should be dead before being eaten, and this is evidence to encourage efforts to outlaw the consumption of live animals to reduce suffering and improve animal welfare [26].

The Eurobarometer survey (EC 2007) [5] of the European Commission for Health and Food Safety found that $60 \%$ of European respondents believed that welfare protection had improved in their country. In China, the attitude part of the survey appears to suggest that the general public mostly support the promotion of animal welfare.

\section{Conclusions}

The majority of the respondents to our survey remained unaware of the meaning of the term 'animal welfare' but the numbers of those that were aware appear to have increased compared with previous studies. Although those that were aware expressed opinions that were positive towards the welfare of animals, the majority considered the care of animals in China to be poor. The role of the popular media in discussing the welfare of animals seems to have improved recently. The respondents that were concerned for the welfare of animals were concerned for the welfare of all taxa and all types of commercial animal uses. A particularly interesting finding, and one that confirms a previous study, was 
the higher value placed on the welfare of wild animals than for other types of animal uses. The survey also showed the importance given to the taste of food and the safety of food from farm animals, and any possible link these might have to the welfare of the animals used; respondents reported that they would be prepared to pay more for such food.

\section{Limitations}

The authors recognize that there were limitations of this study that may restrict the conclusions that can be drawn. The respondents were not necessarily typical of the population of China as a whole, being more evenly matched to the student administrators of the survey, in terms of gender, age and having a higher education level. Likewise, the respondents were more urbanised in this study than the population of China as a whole. This may have been due to the use of student questioners rather than professional market research questioners, and also the sites selected to carry out the questioning. Finally, narratives related to the welfare of animals that might have been important but not predicted by the designers of the questionnaire may have been missed.

Author Contributions: Conceptualization, B.S., X.J., K.D., C.J.C.P., methodology, X.J., K.D., C.J.C.P., resources, (C.J.C.P.), collection data (all student and W.G.); investigation and data curation, F.C. and C.J.C.P., writing-original draft preparation F.C. and D.A.; writing-review and editing F.C., K.D., C.J.C.P. and D.A. All authors have read and agreed to the published version of the manuscript.

Funding: This research project was funded by Open Philanthropy Project in a grant administered through the School of Veterinary Science, University of Queensland.

Institutional Review Board Statement: The questionnaire and survey method were approved by the Human Research Ethics Committee of the University of Queensland, Australia (\#2019001811).

Data Availability Statement: The raw data has not been published or stored elsewhere but is available on request from F.C.

Acknowledgments: We are grateful to Weiqi Wu, Yuanqing Xu, Yuanyuan Xing, Chenyu Mao, Lulu Shi, Shuo Yang, to help for the collection data, all students under the supervision of Jin Xiao, Lecturer in College of Animal Science, Inner Mongolia Agricultural University. We are grateful to Michelle Sinclair for her help to us from the University of Queensland.

Conflicts of Interest: The authors declare no conflict of interest.

\section{Appendix A}

Box A1. Survey Administered to Chinese Respondents.

Location (circle): Rural/Village/City

Province:

1 Do you identify as Chinese? YES (please continue); NO (if no, please do not continue. Thank you for your time)

2 What is your gender? Male; Female; Other; Prefer not to say.

3 How old are you? $18-24 ; 25-34 ; 54-44 ; 45-54 ; 55-64 ;>65$.

4 Religion: Chinese folk; Atheist; Buddhism; Muslim; Christians; Daoism; Confucianism; Prefer not to say; Other.

5 What is your highest level of education? Elementary school or below; Technical college; Middle school; High school; University undergraduate; University postgraduate.

6 Are you currently employed? Yes, No.

7 If yes, what field do you work in? Administration; Agriculture; Arts; Construction; Education; Finance; Government; Health; Mining; Military; Retail/Sales; Science; Technology; Other.

8 Where do you currently live? Rural; Village; Urban; Other.

9 Have you heard of the phrase 'animal welfare'? Not sure; Never; A few times; Many times.

10 Do you live in harmony with animals? Not at all Slightly; Moderately; Very much; To a great extent. 
Box A1. Cont.

Location (circle): Rural/Village/City

Province:

11 How important is caring for animals to you as a person? Not at all Slightly; Moderately; Very; Extremely.

12 Where did you learn about caring for animals? (Tick all that apply) Formal study; Family and friends; Media; Business; My job; Government; Animal protection organization; Social media; Farmer; Have not heard; Other.

13 Do you think that animal care should be taught in schools? Definitely not; Probably not; Possibly; Probably; Definitely.

14 Would you be willing to pay more for products from animals that are better cared for? Yes; No

15 If yes, how much more would you be willing to pay for a product from an animal very well cared for compared with the standard product? $5 \% ; 10 \% ; 20 \% ; 50 \% ; 100 \% ;>100 \%$

16 What do you think is the current standard of animal care in China? Very poor; Poor; Satisfactory

1. Good; Very good.

17 How do you think the standard of animal care in China compares to other countries? Much worse; Somewhat worse; About the same; Better; Much Better.

18 Who do you think is most responsible for the adequate care of animals? (Tick one only) Government; Animal Protection Organizations; Farmers; All of society; People who like animals; People who own animals; Companies that use animals; Other.

19 How important is it that the following animals are cared for?

Location (circle): Rural/Village/City

(Not at all important; Slightly important; Neither important nor unimportant; Somewhat important; Very important.)

19.1 Mammals

19.2 Reptiles

19.3 Birds

19.4 Insects

19.5 Pet animals

19.6 Experimental animals

19.7 Agricultural animals

19.8 Stray animals

19.9 Wildlife

20 Why do people take care of farm animals? Indicate how strongly you agree or disagree with the following reasons

(Strongly disagree; Disagree; Neither agree nor disagree; Agree; Strongly agree.)

20.1 It is important for food safety

20.2 It is important for sake of the environment

20.3 It makes me feel good

20.4 My religion tells me to

20.5 It is good for human health

20.6 For sake of the animals

20.7 To improve profit from animals

20.8 To improve product quality or taste

20.9 To be a kind person

21 How important are the following conditions in animal care?

(Not at all important; Slightly important; Neither important nor unimportant; Somewhat important; Very important.)

21.1 Species-relevant nutrition

21.2 Access to drinking water

21.3 A comfortable environment

21.4 Space

21.5 Physical fitness

21.6 Absence of disease or injury

21.7 Control over their environment

21.8 Opportunity to perform natural behaviours

21.9 Absence of fear or distress

21.10 Absence of pain

22 Indicate your level of agreement with the following statements 
Box A1. Cont.
Location (circle): Rural/Village/City
Province:
(Strongly disagree; Disagree; Neither agree nor disagree; Agree; Strongly agree.)
22.1 Farms with animals should be certified by animal protection organizations
22.2 Procedures performed on animals such as ear tags, castrations and tail docking are acceptable for management
22.3 Transportation time of live animals should be minimized
22.4 Animals on farms should be provided with enjoyable experiences
22.5 It is OK to buy products of animals that have suffered if the product quality is good enough
22.6 It is OK to buy products of animals that have suffered if the price is low enough
22.7 Animals should be unconscious (stunned) before they are killed
22.8 Animals should be killed before being cooked
22.9 It is important to have legislation that ensures animal care is adequate
22.10 Animal protection organization are important in ensuring animals are adequately cared for

Table A1. Show the relative perceptions of attitudes towards animal taxa different species in China and the answers for different species significant with Ordinal Logistic Regression.

\begin{tabular}{|c|c|c|c|}
\hline \multicolumn{2}{|c|}{ How Important Is It That the Following Animals Are Cared for? } & \multirow{2}{*}{$\frac{\text { Number of Respondents }}{40}$} & \multirow{2}{*}{$\frac{\% \text { of Survey Sample }}{3}$} \\
\hline \multirow{5}{*}{ Mammals } & Not at all important & & \\
\hline & Slightly important & 35 & 2 \\
\hline & Neither important nor unimportant & 142 & 10 \\
\hline & Somewhat important & 676 & 52 \\
\hline & Very important & 407 & 31 \\
\hline \multirow{5}{*}{ Reptiles } & Not at all important & 18 & 1 \\
\hline & Slightly important & 74 & 5 \\
\hline & Neither important nor unimportant & 186 & 14 \\
\hline & Somewhat important & 631 & 48 \\
\hline & Very important & 389 & 29 \\
\hline \multirow{5}{*}{ Birds } & Not at all important & 19 & 1 \\
\hline & Slightly important & 46 & 3 \\
\hline & Neither important nor unimportant & 191 & 14 \\
\hline & Somewhat important & 617 & 47 \\
\hline & Very important & 427 & 32 \\
\hline \multirow{5}{*}{ Insects } & Not at all important & 41 & 3 \\
\hline & Slightly important & 95 & 7 \\
\hline & Neither important nor unimportant & 258 & 19 \\
\hline & Somewhat important & 529 & 40 \\
\hline & Very important & 375 & 28 \\
\hline \multirow{5}{*}{ Pet animals } & Not at all important & 10 & 0.7 \\
\hline & Slightly important & 39 & 3 \\
\hline & Neither important nor unimportant & 161 & 20 \\
\hline & Somewhat important & 588 & 45 \\
\hline & Very important & 501 & 38 \\
\hline \multirow{5}{*}{ Experimental animals } & Not at all important & 14 & 1 \\
\hline & Slightly important & 29 & 2 \\
\hline & Neither important nor unimportant & 164 & 12 \\
\hline & Somewhat important & 573 & 44 \\
\hline & Very important & 518 & 39 \\
\hline
\end{tabular}


Table A1. Cont.

\begin{tabular}{|c|c|c|c|}
\hline \multicolumn{2}{|c|}{ How Important Is It That the Following Animals Are Cared for? } & \multirow{2}{*}{$\begin{array}{c}\text { Number of Respondents } \\
17\end{array}$} & \multirow{2}{*}{$\frac{\text { \% of Survey Sample }}{1}$} \\
\hline \multirow{5}{*}{ Agricultural animals } & Not at all important & & \\
\hline & Slightly important & 27 & 2 \\
\hline & Neither important nor unimportant & 138 & 10 \\
\hline & Somewhat important & 589 & 45 \\
\hline & Very important & 527 & 40 \\
\hline \multirow{5}{*}{ Stray animals } & Not at all important & 21 & 1 \\
\hline & Slightly important & 39 & 3 \\
\hline & Neither important nor unimportant & 179 & 13 \\
\hline & Somewhat important & 566 & 43 \\
\hline & Very important & 494 & 38 \\
\hline \multirow{5}{*}{ Wildlife } & Not at all important & 18 & 1 \\
\hline & Slightly important & 37 & 2 \\
\hline & Neither important nor unimportant & 134 & 10 \\
\hline & Somewhat important & 508 & 39 \\
\hline & Very important & 600 & 46 \\
\hline
\end{tabular}

Table A2. The relative perceptions of attitudes towards different animal taxa in China. Significant $(p<0.05)$ differences in the relative perceptions of the importance of looking after different animal groups in China, analysed by Ordinal Logistic Regression.

\begin{tabular}{|c|c|c|c|c|c|}
\hline \multicolumn{2}{|c|}{ Mammals vs. Other Species Groups } & Odds Ratio & \multicolumn{2}{|c|}{$\% 95 \mathrm{CI}$} & $p$-Value \\
\hline & & \multicolumn{4}{|c|}{ Lower Upper } \\
\hline \multirow{3}{*}{ Reptiles } & Neither important nor unimportant & 0.2 & 0.05 & 0.5 & 0.004 \\
\hline & Somewhat important & 0.01 & 0.001 & 0.05 & 0.0001 \\
\hline & Very important & 0.001 & 0.001 & 0.01 & 0.0001 \\
\hline \multirow{2}{*}{ Birds } & Somewhat important & 0.2 & 0.05 & 0.9 & 0.03 \\
\hline & Very important & 0.05 & 0.01 & 0.2 & 0.0001 \\
\hline \multirow{4}{*}{ Insects } & Slightly important & 5.04 & 1.8 & 13.6 & 0.001 \\
\hline & Neither important nor unimportant & 4.6 & 1.7 & 12.1 & 0.002 \\
\hline & Somewhat important & 9.4 & 3.5 & 24.9 & 0.0001 \\
\hline & Very important & 4.7 & 1.7 & 13.1 & 0.003 \\
\hline Pet animals & Very important & 0.2 & 0.04 & 0.9 & 0.04 \\
\hline \multirow{3}{*}{$\begin{array}{l}\text { Agricultural } \\
\text { animals }\end{array}$} & Slightly important & 0.1 & 0.04 & 0.8 & 0.03 \\
\hline & Somewhat important & 0.2 & 0.05 & 0.8 & 0.02 \\
\hline & Very important & 0.1 & 0.02 & 0.4 & 0.001 \\
\hline \multirow{4}{*}{ Stray animals } & Slightly important & 14.3 & 3.9 & 52.8 & 0.0001 \\
\hline & Neither important nor unimportant & 6.1 & 1.8 & 20.1 & 0.003 \\
\hline & Somewhat important & 5.3 & 1.6 & 17.1 & 0.004 \\
\hline & Very important & 3.7 & 1.1 & 12.1 & 0.02 \\
\hline \multirow{3}{*}{ Wildlife } & Slightly important & 0.2 & 0.07 & 0.9 & 0.03 \\
\hline & Somewhat important & 0.3 & 0.1 & 0.9 & 0.03 \\
\hline & Very important & 0.2 & 0.08 & 0.7 & 0.01 \\
\hline
\end{tabular}


Table A2. Cont.

\begin{tabular}{|c|c|c|c|c|c|}
\hline Repti & vs. Other Species Groups & & & & \\
\hline \multirow{4}{*}{ Mammals } & Slightly important & 0.08 & 0.03 & 0.2 & 0.0001 \\
\hline & Neither important nor unimportant & 0.02 & 0.01 & 0.06 & 0.0001 \\
\hline & Somewhat important & 0.001 & 0.001 & 0.01 & 0.0001 \\
\hline & Very important & 0.001 & 0.001 & 0.001 & 0.0001 \\
\hline Birds & Very important & 0.2 & 0.06 & 0.8 & 0.03 \\
\hline \multirow[b]{2}{*}{ Insects } & Somewhat important & 0.1 & 0.05 & 0.2 & 0.0001 \\
\hline & Very important & 0.03 & 0.01 & 0.08 & 0.0001 \\
\hline $\begin{array}{l}\text { Experimental } \\
\text { animals }\end{array}$ & Neither important nor unimportant & 8.7 & 1.6 & 48.2 & 0.01 \\
\hline \multirow{2}{*}{$\begin{array}{l}\text { Agricultural } \\
\text { animals }\end{array}$} & Neither important nor unimportant & 0.1 & 0.04 & 0.7 & 0.02 \\
\hline & Very important & 0.1 & 0.04 & 0.8 & 0.02 \\
\hline \multirow[t]{2}{*}{ Stray animals } & Slightly important & 0.2 & 0.08 & 1 & 0.04 \\
\hline & Neither important nor unimportant & 0.1 & 0.06 & 0.5 & 0.004 \\
\hline \multirow[t]{2}{*}{ Wildlife } & Somewhat important & 0.1 & 0.06 & 0.5 & 0.003 \\
\hline & Very important & 0.1 & 0.06 & 0.5 & 0.002 \\
\hline \multicolumn{6}{|c|}{ Birds vs. other species groups } \\
\hline \multirow{3}{*}{ Mammals } & Neither important nor unimportant & 0.3 & 0.1 & 0.9 & 0.04 \\
\hline & Somewhat important & 0.1 & 0.07 & 0.5 & 0.001 \\
\hline & Very important & 0.03 & 0.01 & 0.09 & 0.0001 \\
\hline \multirow{4}{*}{ Reptiles } & Slightly important & 0.07 & 0.02 & 0.2 & 0.0001 \\
\hline & Neither important nor unimportant & 0.05 & 0.01 & 0.1 & 0.0001 \\
\hline & Somewhat important & 0.02 & 0.001 & 0.07 & 0.0001 \\
\hline & Very important & 0.01 & 0.001 & 0.03 & 0.0001 \\
\hline \multirow{4}{*}{ Insects } & Slightly important & 0.03 & 0.01 & 0.07 & 0.0001 \\
\hline & Neither important nor unimportant & 0.03 & 0.01 & 0.07 & 0.0001 \\
\hline & Somewhat important & 0.02 & 0.01 & 0.05 & 0.0001 \\
\hline & Very important & 0.01 & 0.001 & 0.02 & 0.0001 \\
\hline \multirow{2}{*}{$\begin{array}{l}\text { Agricultural } \\
\text { animals }\end{array}$} & Slightly important & 5.9 & 1.1 & 29.6 & 0.03 \\
\hline & Neither important nor unimportant & 5.9 & 1.2 & 27.3 & 0.02 \\
\hline \multirow{3}{*}{ Stray animals } & Neither important nor unimportant & 0.2 & 0.08 & 0.7 & 0.01 \\
\hline & Somewhat important & 0.2 & 0.08 & 0.6 & 0.009 \\
\hline & Very important & 0.2 & 0.07 & 0.6 & 0.006 \\
\hline Wildlife & Very important & 0.2 & 0.09 & 0.8 & 0.02 \\
\hline \multicolumn{6}{|c|}{ Insects vs. other Species Groups } \\
\hline \multirow{4}{*}{ Mammals } & Slightly important & 3.8 & 1.3 & 10.6 & 0.01 \\
\hline & Neither important nor unimportant & 7.6 & 2.8 & 20.6 & 0.0001 \\
\hline & Somewhat important & 11.8 & 4.5 & 31.1 & 0.0001 \\
\hline & Very important & 10.3 & 3.7 & 28.4 & 0.0001 \\
\hline \multirow{2}{*}{ Reptiles } & Somewhat important & 0.1 & 0.03 & 0.4 & 0.003 \\
\hline & Very important & 0.02 & 0.001 & 0.07 & 0.0001 \\
\hline \multirow{4}{*}{ Birds } & Slightly important & 0.03 & 0.01 & 0.1 & 0.0001 \\
\hline & Neither important nor unimportant & 0.001 & 0.001 & 0.02 & 0.0001 \\
\hline & Somewhat important & 0.001 & 0.001 & 0.01 & 0.0001 \\
\hline & Very important & 0.001 & 0.001 & 0.01 & 0.0001 \\
\hline
\end{tabular}


Table A2. Cont.

\begin{tabular}{|c|c|c|c|c|c|}
\hline Inse & vs. other Species Groups & & & & \\
\hline \multirow{4}{*}{ Pet animals } & Slightly important & 0.03 & 0.001 & 0.2 & 0.0001 \\
\hline & Neither important nor unimportant & 0.04 & 0.01 & 0.2 & 0.0001 \\
\hline & Somewhat important & 0.03 & 0.01 & 0.1 & 0.0001 \\
\hline & Very important & 0.02 & 0.001 & 0.1 & 0.0001 \\
\hline \multirow{4}{*}{$\begin{array}{l}\text { Experimental } \\
\text { animals }\end{array}$} & Slightly important & 0.1 & 0.02 & 0.5 & 0.006 \\
\hline & Neither important nor unimportant & 0.1 & 0.02 & 0.6 & 0.01 \\
\hline & Somewhat important & 0.1 & 0.03 & 0.7 & 0.02 \\
\hline & Very important & 0.09 & 0.02 & 0.4 & 0.005 \\
\hline \multirow{2}{*}{$\begin{array}{l}\text { Agricultural } \\
\text { animals }\end{array}$} & Somewhat important & 5.08 & 1.1 & 22.06 & 0.03 \\
\hline & Very important & 8.3 & 1.9 & 36.4 & 0.005 \\
\hline \multirow{2}{*}{ Stray animals } & Somewhat important & 0.2 & 0.07 & 0.6 & 0.007 \\
\hline & Very important & 0.1 & 0.05 & 0.5 & 0.002 \\
\hline \multicolumn{6}{|c|}{ Pet Animals vs. other Species Groups } \\
\hline Mammals & Slightly important & 6.07 & 2.1 & 17.1 & 0.001 \\
\hline \multirow{3}{*}{ Birds } & Neither important nor unimportant & 0.1 & 0.03 & 0.3 & 0.0001 \\
\hline & Somewhat important & 0.1 & 0.03 & 0.3 & 0.0001 \\
\hline & Very important & 0.08 & 0.02 & 0.2 & 0.0001 \\
\hline \multirow{3}{*}{ Insects } & Slightly important & 4.1 & 1.6 & 10.4 & 0.003 \\
\hline & Neither important nor unimportant & 5.6 & 3.3 & 13.9 & 0.0001 \\
\hline & Somewhat important & 2.7 & 1.1 & 6.8 & 0.02 \\
\hline \multirow{4}{*}{$\begin{array}{l}\text { Experimental } \\
\text { animals }\end{array}$} & Slightly important & 0.09 & 0.02 & 0.4 & 0.002 \\
\hline & Neither important nor unimportant & 0.01 & 0.001 & 0.07 & 0.0001 \\
\hline & Somewhat important & 0.01 & 0.001 & 0.04 & 0.0001 \\
\hline & Very important & 0.001 & 0.001 & 0.01 & 0.0001 \\
\hline Wildlife & Slightly important & 0.1 & 0.03 & 0.4 & 0.001 \\
\hline \multicolumn{6}{|c|}{ Experimental Animals vs. other Species Groups } \\
\hline \multirow{2}{*}{ Birds } & Somewhat important & 0.1 & 0.03 & 0.4 & 0.003 \\
\hline & Very important & 0.2 & 0.05 & 0.7 & 0.02 \\
\hline Pet animals & Very important & 0.2 & 0.05 & 1 & 0.05 \\
\hline \multirow{4}{*}{$\begin{array}{l}\text { Agricultural } \\
\text { animals }\end{array}$} & Slightly important & 0.07 & 0.02 & 0.3 & 0.0001 \\
\hline & Neither important nor unimportant & 0.01 & 0.001 & 0.05 & 0.0001 \\
\hline & Somewhat important & 0.001 & 0.001 & 0.02 & 0.0001 \\
\hline & Very important & 0.001 & 0.001 & 0.001 & 0.0001 \\
\hline \multirow{4}{*}{ Stray animals } & Slightly important & 0.1 & 0.05 & 0.5 & 0.005 \\
\hline & Neither important nor unimportant & 0.2 & 0.07 & 0.6 & 0.008 \\
\hline & Somewhat important & 0.3 & 0.1 & 0.8 & 0.029 \\
\hline & Very important & 0.1 & 0.06 & 0.5 & 0.003 \\
\hline Wildlife & Slightly important & 5.4 & 1.4 & 20.7 & 0.01 \\
\hline
\end{tabular}


Table A2. Cont.

\begin{tabular}{|c|c|c|c|c|c|}
\hline \multicolumn{6}{|c|}{ Agricultural Animals vs. other Species Groups } \\
\hline \multirow{2}{*}{ Mammals } & Somewhat important & 0.3 & 0.1 & 0.8 & 0.02 \\
\hline & Very important & 0.1 & 0.04 & 0.3 & 0.0001 \\
\hline \multirow{3}{*}{ Reptiles } & Neither important nor unimportant & 0.1 & 0.05 & 0.6 & 0.01 \\
\hline & Somewhat important & 0.1 & 0.05 & 0.6 & 0.01 \\
\hline & Very important & 0.1 & 0.04 & 0.5 & 0.005 \\
\hline Insects & Very important & 4.2 & 1.5 & 11.5 & 0.005 \\
\hline \multirow{4}{*}{$\begin{array}{l}\text { Experimental } \\
\text { animals }\end{array}$} & Slightly important & 0.2 & 0.05 & 0.8 & 0.03 \\
\hline & Neither important nor unimportant & 0.04 & 0.01 & 0.1 & 0.0001 \\
\hline & Somewhat important & 0.01 & 0.001 & 0.05 & 0.0001 \\
\hline & Very important & 0.001 & 0.001 & 0.01 & 0.0001 \\
\hline Stray animals & Very important & 0.3 & 0.1 & 0.9 & 0.03 \\
\hline \multicolumn{6}{|c|}{ Stray animals vs. other species groups } \\
\hline \multirow{2}{*}{ Insects } & Somewhat important & 0.4 & 0.1 & 0.9 & 0.03 \\
\hline & Very important & 0.2 & 0.1 & 0.6 & 0.003 \\
\hline \multirow{2}{*}{ Pet animals } & Slightly important & 7.02 & 1.4 & 34.3 & 0.01 \\
\hline & Neither important nor unimportant & 4.6 & 1.01 & 21.4 & 0.04 \\
\hline \multirow{3}{*}{$\begin{array}{l}\text { Agricultural } \\
\text { animals }\end{array}$} & Neither important nor unimportant & 0.1 & 0.03 & 0.4 & 0.002 \\
\hline & Somewhat important & 0.1 & 0.03 & 0.4 & 0.001 \\
\hline & Very important & 0.05 & 0.01 & 0.2 & 0.0001 \\
\hline \multirow{3}{*}{ Wildlife } & Slightly important & 4.8 & 1.4 & 16.1 & 0.01 \\
\hline & Neither important nor unimportant & 3.5 & 1.1 & 10.7 & 0.02 \\
\hline & Very important & 0.3 & 0.1 & 0.9 & 0.003 \\
\hline \multicolumn{6}{|c|}{ Wildlife vs. other Species Groups } \\
\hline Birds & Very important & 0.1 & 0.04 & 0.5 & 0.005 \\
\hline \multirow{2}{*}{$\begin{array}{l}\text { Experimental } \\
\text { animals }\end{array}$} & Somewhat important & 0.2 & 0.04 & 0.8 & 0.03 \\
\hline & Very important & 0.1 & 0.04 & 0.8 & 0.02 \\
\hline \multirow{2}{*}{ Stray animals } & Somewhat important & 0.2 & 0.1 & 0.7 & 0.01 \\
\hline & Very important & 0.05 & 0.02 & 0.1 & 0.0001 \\
\hline
\end{tabular}

Table A3. Significant $(p<0.05)$ differences in the reasons that Chinese respondents indicated that they cared for animals, determined by Ordinal Logistic Regression.

\begin{tabular}{|c|c|c|c|c|c|}
\hline \multicolumn{2}{|c|}{ For Food Safety vs. Other Reasons } & Odds Ratio & \multicolumn{2}{|c|}{$\% 95$ CI } & $p$-Value \\
\hline & & \multicolumn{4}{|c|}{ Lower Upper } \\
\hline \multirow{3}{*}{$\begin{array}{l}\text { It is important for sake of } \\
\text { the environment }\end{array}$} & Neither agree nor disagree & 0.04 & 0.01 & 0.1 & 0.0001 \\
\hline & Agree & 0.01 & 0.001 & 0.02 & 0.0001 \\
\hline & Strongly agree & 0.001 & 0.001 & 0.001 & 0.0001 \\
\hline \multirow{2}{*}{ For sake of the animals } & Neither agree nor disagree & 2.5 & 1.05 & 5.9 & 0.04 \\
\hline & Agree & 2.7 & 1.1 & 6.3 & 0.02 \\
\hline \multirow{3}{*}{$\begin{array}{l}\text { To improve profit from } \\
\text { animals }\end{array}$} & Neither agree nor disagree & 0.1 & 0.04 & 0.8 & 0.03 \\
\hline & Agree & 0.2 & 0.05 & 0.8 & 0.002 \\
\hline & Strongly agree & 0.1 & 0.02 & 0.4 & 0.0001 \\
\hline
\end{tabular}


Table A3. Cont.

\begin{tabular}{|c|c|c|c|c|c|}
\hline \multicolumn{6}{|c|}{ For the Sake of the Environment vs. other Reasons } \\
\hline \multirow{4}{*}{$\begin{array}{l}\text { It is important for food } \\
\text { safety }\end{array}$} & Disagree & 0.06 & 0.02 & 0.1 & 0.0001 \\
\hline & Neither agree nor disagree & 0.07 & 0.01 & 0.07 & 0.0001 \\
\hline & Agree & 0.01 & 0.001 & 0.01 & 0.0001 \\
\hline & Strongly agree & 0.001 & 0.001 & 0.001 & 0.0001 \\
\hline It makes me feel good & Strongly agree & 0.2 & 0.06 & 0.9 & 0.04 \\
\hline \multirow{2}{*}{ My religion tells me to } & Disagree & 2.5 & 1.3 & 7.1 & 0.01 \\
\hline & Agree & 2.3 & 1.2 & 5.6 & 0.01 \\
\hline \multirow{2}{*}{$\begin{array}{l}\text { It is good for human } \\
\text { health }\end{array}$} & Agree & 0.2 & 0.07 & 0.6 & 0.005 \\
\hline & Strongly agree & 0.2 & 0.06 & 0.6 & 0.004 \\
\hline \multirow{3}{*}{$\begin{array}{l}\text { To improve product } \\
\text { quality or taste }\end{array}$} & Neither agree nor disagree & 0.2 & 0.07 & 0.5 & 0.003 \\
\hline & Agree & 0.2 & 0.07 & 0.5 & 0.002 \\
\hline & Strongly agree & 0.1 & 0.04 & 0.3 & 0.0001 \\
\hline \multicolumn{6}{|c|}{ It Makes Me Feel Good vs. Other Reasons } \\
\hline \multirow{2}{*}{$\begin{array}{l}\text { It is important for food } \\
\text { safety }\end{array}$} & Agree & 0.03 & 0.1 & 0.6 & 0.004 \\
\hline & Strongly agree & 0.02 & 0.08 & 0.5 & 0.0001 \\
\hline \multirow{4}{*}{$\begin{array}{l}\text { It is important for sake of } \\
\text { the environment }\end{array}$} & Disagree & 0.1 & 0.04 & 0.5 & 0.003 \\
\hline & Neither agree nor disagree & 0.1 & 0.03 & 0.4 & 0.002 \\
\hline & Agree & 0.05 & 0.01 & 0.2 & 0.0001 \\
\hline & Strongly agree & 0.02 & 0.01 & 0.08 & 0.0001 \\
\hline \multirow{2}{*}{ My religion tells me to } & Agree & 0.3 & 0.2 & 0.7 & 0.002 \\
\hline & Strongly agree & 0.1 & 0.06 & 0.2 & 0.0001 \\
\hline $\begin{array}{l}\text { It is good for human } \\
\text { health }\end{array}$ & Strongly agree & 0.1 & 0.06 & 0.5 & 0.001 \\
\hline \multirow{4}{*}{$\begin{array}{c}\text { To improve profit from } \\
\text { animals }\end{array}$} & Disagree & 3.4 & 1.5 & 7.9 & 0.004 \\
\hline & Neither agree nor disagree & 4.8 & 2.2 & 10.4 & 0.0001 \\
\hline & Agree & 4.3 & 2 & 9.1 & 0.0001 \\
\hline & Strongly agree & 3.2 & 1.4 & 7.1 & 0.004 \\
\hline \multirow{4}{*}{$\begin{array}{l}\text { To improve product } \\
\text { quality or taste }\end{array}$} & Disagree & 0.2 & 0.06 & 0.6 & 0.003 \\
\hline & Neither agree nor disagree & 0.2 & 0.09 & 0.7 & 0.005 \\
\hline & Agree & 0.2 & 0.06 & 0.4 & 0.0001 \\
\hline & Strongly agree & 0.1 & 0.04 & 0.3 & 0.0001 \\
\hline \multicolumn{6}{|c|}{ My Religion Tells Me to vs. Other Reasons } \\
\hline \multirow{4}{*}{ It makes me feel good } & Disagree & 0.06 & 0.02 & 0.2 & 0.0001 \\
\hline & Neither agree nor disagree & 0.04 & 0.01 & 0.1 & 0.0001 \\
\hline & Agree & 0.02 & 0.001 & 0.06 & 0.0001 \\
\hline & Strongly agree & 0.01 & 0.001 & 0.02 & 0.0001 \\
\hline $\begin{array}{l}\text { It is good for human } \\
\text { health }\end{array}$ & Strongly agree & 0.2 & 0.08 & 0.5 & 0.002 \\
\hline \multirow{2}{*}{$\begin{array}{c}\text { To improve product } \\
\text { quality or taste }\end{array}$} & Disagree & 4.2 & 1.4 & 13.03 & 0.01 \\
\hline & Neither agree nor disagree & 3.08 & 1.1 & 8.3 & 0.02 \\
\hline
\end{tabular}


Table A3. Cont.

\begin{tabular}{|c|c|c|c|c|c|}
\hline \multicolumn{6}{|c|}{ It is good for Human Health vs. other Reasons } \\
\hline $\begin{array}{l}\text { It is important for food } \\
\text { safety }\end{array}$ & Agree & 2.5 & 1.01 & 6.01 & 0.04 \\
\hline \multirow{4}{*}{$\begin{array}{l}\text { It is important for sake of } \\
\text { the environment }\end{array}$} & Disagree & 0.2 & 0.07 & 0.8 & 0.02 \\
\hline & Neither agree nor disagree & 0.3 & 0.07 & 0.9 & 0.003 \\
\hline & Agree & 0.2 & 0.04 & 0.6 & 0.005 \\
\hline & Strongly agree & 0.1 & 0.03 & 0.4 & 0.001 \\
\hline \multirow{3}{*}{ It makes me feel good } & Neither agree nor disagree & 0.2 & 0.07 & 0.8 & 0.015 \\
\hline & Agree & 0.09 & 0.03 & 0.3 & 0.0001 \\
\hline & Strongly agree & 0.05 & 0.02 & 0.2 & 0.0001 \\
\hline My religion tells me to & Strongly agree & 0.2 & 0.1 & 0.4 & 0.0001 \\
\hline \multirow{3}{*}{$\begin{array}{l}\text { To improve profit from } \\
\text { animals }\end{array}$} & Neither agree nor disagree & 0.3 & 0.1 & 0.6 & 0.002 \\
\hline & Agree & 0.4 & 0.2 & 0.8 & 0.01 \\
\hline & Strongly agree & 0.5 & 0.2 & 1.02 & 0.05 \\
\hline $\begin{array}{l}\text { To improve product } \\
\text { quality or taste }\end{array}$ & Strongly agree & 0.3 & 0.13 & 0.9 & 0.02 \\
\hline \multicolumn{6}{|c|}{ For the Sake of the Animal vs. other reasons } \\
\hline \multirow{2}{*}{ My religion tells me to } & Agree & 0.4 & 0.2 & 0.7 & 0.002 \\
\hline & Strongly agree & 0.2 & 0.1 & 0.4 & 0.0001 \\
\hline $\begin{array}{l}\text { It is good for human } \\
\text { health }\end{array}$ & Strongly agree & 0.3 & 0.1 & 0.9 & 0.03 \\
\hline \multirow{4}{*}{$\begin{array}{l}\text { To improve profit from } \\
\text { animals }\end{array}$} & Disagree & 0.15 & 0.07 & 0.31 & 0.0001 \\
\hline & Neither agree nor disagree & 0.03 & 0.01 & 0.06 & 0.0001 \\
\hline & Agree & 0.01 & 0.001 & 0.02 & 0.0001 \\
\hline & Strongly agree & 0.001 & 0.001 & 0.001 & 0.0001 \\
\hline $\begin{array}{l}\text { To improve product } \\
\text { quality or taste }\end{array}$ & Disagree & 4.3 & 1.3 & 13.9 & 0.013 \\
\hline \multicolumn{6}{|c|}{ To Improve Profit from Animals' vs. other reasons } \\
\hline $\begin{array}{l}\text { It is important for food } \\
\text { safety }\end{array}$ & Strongly agree & 0.24 & 0.09 & 0.6 & 0.002 \\
\hline \multirow{3}{*}{$\begin{array}{l}\text { It is good for human } \\
\text { health }\end{array}$} & Neither agree nor disagree & 0.2 & 0.1 & 0.8 & 0.02 \\
\hline & Agree & 0.3 & 0.1 & 0.9 & 0.03 \\
\hline & Strongly agree & 0.4 & 0.1 & 0.9 & 0.04 \\
\hline \multirow{4}{*}{ For sake of the animals } & Disagree & 0.09 & 0.05 & 0.19 & 0.0001 \\
\hline & Neither agree nor disagree & 0.03 & 0.01 & 0.05 & 0.0001 \\
\hline & Agree & 0.01 & 0.001 & 0.01 & 0.0001 \\
\hline & Strongly agree & 0.001 & 0.001 & 0.001 & 0.0001 \\
\hline \multicolumn{6}{|c|}{ To Improve Product Quality or Taste vs. other reasons } \\
\hline \multirow{2}{*}{ It makes me feel good } & Agree & 0.3 & 0.09 & 0.95 & 0.04 \\
\hline & Strongly agree & 0.2 & 0.06 & 0.6 & 0.004 \\
\hline My religion tells me to & Strongly agree & 0.3 & 0.1 & 0.7 & 0.005 \\
\hline \multirow{3}{*}{$\begin{array}{l}\text { To improve profit from } \\
\text { animals }\end{array}$} & Disagree & 4.7 & 2.07 & 10.8 & 0.0001 \\
\hline & Neither agree nor disagree & 4.8 & 2.2 & 10.3 & 0.0001 \\
\hline & Agree & 3.6 & 1.7 & 7.7 & 0.001 \\
\hline
\end{tabular}


Table A4. Significant $(p<0.05)$ differences in attributed importance levels to different conditions for animal care, analysed by Ordinal Logistic Regression.

\begin{tabular}{|c|c|c|c|c|c|}
\hline \multicolumn{2}{|c|}{ Species-Relevant Nutrition } & Odds Ratio & \multicolumn{2}{|c|}{$\% 95 \mathrm{CI}$} & $p$-Value \\
\hline & & \multicolumn{4}{|c|}{ Lower Upper } \\
\hline \multirow{3}{*}{ Access to drinking water } & $\begin{array}{l}\text { Neither important nor } \\
\text { unimportant }\end{array}$ & 0.01 & 0.001 & 0.23 & 0.003 \\
\hline & Somewhat important & 0.001 & 0.001 & 0.05 & 0.0001 \\
\hline & Very important & 0.001 & 0.001 & 0.01 & 0.0001 \\
\hline A comfortable environment & Very important & 0.08 & 0.01 & 0.88 & 0.03 \\
\hline \multirow{4}{*}{ Absence of fear or distress } & Slightly important & 0.03 & 0.01 & 0.2 & 0.0001 \\
\hline & $\begin{array}{l}\text { Neither important nor } \\
\text { unimportant }\end{array}$ & 0.01 & 0.1 & 0.04 & 0.0001 \\
\hline & Somewhat important & 0.01 & 0.07 & 0.07 & 0.0001 \\
\hline & Very important & 0.01 & 0.06 & 0.04 & 0.0001 \\
\hline Absence of pain & Slightly important & 0.08 & 0.01 & 0.6 & 0.01 \\
\hline \multicolumn{6}{|c|}{ Access to Drinking Water } \\
\hline \multirow{4}{*}{ Species-relevant nutrition } & Slightly important & 0.04 & 0.01 & 0.16 & 0.0001 \\
\hline & $\begin{array}{l}\text { Neither important nor } \\
\text { unimportant }\end{array}$ & 0.02 & 0.001 & 0.07 & 0.0001 \\
\hline & Somewhat important & 0.001 & 0.001 & 0.01 & 0.0001 \\
\hline & Very important & 0.001 & 0.001 & 0.001 & 0.0001 \\
\hline \multirow{2}{*}{ A comfortable environment } & Somewhat important & 0.03 & 0.001 & 0.25 & 0.001 \\
\hline & Very important & 0.01 & 0.001 & 0.05 & 0.0001 \\
\hline \multirow{3}{*}{ Space } & $\begin{array}{l}\text { Neither important nor } \\
\text { unimportant }\end{array}$ & 0.01 & 0.001 & 0.7 & 0.03 \\
\hline & Somewhat important & 0.02 & 0.001 & 0.8 & 0.04 \\
\hline & Very important & 0.01 & 0.001 & 0.5 & 0.02 \\
\hline \multirow{3}{*}{$\begin{array}{l}\text { Opportunity to perform natural } \\
\text { behaviours }\end{array}$} & $\begin{array}{l}\text { Neither important nor } \\
\text { unimportant }\end{array}$ & 0.1 & 0.01 & 1 & 0.05 \\
\hline & Somewhat important & 0.07 & 0.01 & 0.7 & 0.02 \\
\hline & Very important & 0.04 & 0.001 & 0.4 & 0.006 \\
\hline \multicolumn{6}{|c|}{ A Comfortable Environment } \\
\hline \multirow{3}{*}{ Species-relevant nutrition } & $\begin{array}{c}\text { Neither important nor } \\
\text { unimportant }\end{array}$ & 0.3 & 0.08 & 0.9 & 0.04 \\
\hline & Somewhat important & 0.3 & 0.08 & 0.9 & 0.05 \\
\hline & Very important & 0.1 & 0.04 & 0.4 & 0.002 \\
\hline \multirow{4}{*}{ Access to drinking water } & Slightly important & 0.1 & 0.02 & 0.9 & 0.04 \\
\hline & $\begin{array}{l}\text { Neither important nor } \\
\text { unimportant }\end{array}$ & 0.03 & 0.001 & 0.3 & 0.003 \\
\hline & Somewhat important & 0.01 & 0.001 & 0.1 & 0.0001 \\
\hline & Very important & 0.001 & 0.001 & 0.02 & 0.0001 \\
\hline Control over their environment & $\begin{array}{l}\text { Neither important nor } \\
\text { unimportant }\end{array}$ & 0.1 & 0.03 & 0.8 & 0.03 \\
\hline \multicolumn{6}{|c|}{ Space } \\
\hline Species-relevant nutrition & Slightly important & 5.5 & 1.42 & 21.68 & 0.01 \\
\hline \multirow{3}{*}{ Access to drinking water } & $\begin{array}{l}\text { Neither important nor } \\
\text { unimportant }\end{array}$ & 0.05 & 0.001 & 0.72 & 0.02 \\
\hline & Somewhat important & 0.03 & 0.001 & 0.48 & 0.01 \\
\hline & Very important & 0.02 & 0.001 & 0.35 & 0.007 \\
\hline \multirow{2}{*}{ A comfortable environment } & Somewhat important & 0.06 & 0.01 & 0.47 & 0.007 \\
\hline & Very important & 0.01 & 0.0001 & 0.06 & 0.0001 \\
\hline \multirow{3}{*}{ Physical fitness } & $\begin{array}{l}\text { Neither important nor } \\
\text { unimportant }\end{array}$ & 0.01 & 0.001 & 0.3 & 0.005 \\
\hline & Somewhat important & 0.02 & 0.001 & 0.3 & 0.006 \\
\hline & Very important & 0.001 & 0.001 & 0.06 & 0.0001 \\
\hline \multirow{3}{*}{$\begin{array}{c}\text { Opportunity to perform natural } \\
\text { behaviours }\end{array}$} & Slightly important & 12.6 & 1.3 & 119.1 & 0.03 \\
\hline & $\begin{array}{l}\text { Neither important nor } \\
\text { unimportant }\end{array}$ & 21.7 & 2.3 & 205.3 & 0.007 \\
\hline & Somewhat important & 17.24 & 1.8 & 165.6 & 0.01 \\
\hline \multirow{2}{*}{ Absence of fear or distress } & Somewhat important & 6.3 & 1.2 & 32.3 & 0.02 \\
\hline & Very important & 5.9 & 1.1 & 31.5 & 0.03 \\
\hline \multirow{2}{*}{ Absence of pain } & Somewhat important & 0.2 & 0.03 & 0.9 & 0.03 \\
\hline & Very important & 0.1 & 0.02 & 0.7 & 0.01 \\
\hline
\end{tabular}


Table A4. Cont.

\begin{tabular}{|c|c|c|c|c|c|}
\hline \multicolumn{6}{|c|}{ Physical Fitness } \\
\hline \multirow{4}{*}{ Access to drinking water } & Slightly important & 0.02 & 0.001 & 0.2 & 0.0001 \\
\hline & Neither important nor unimportant & 0.05 & 0.001 & 0.5 & 0.01 \\
\hline & Somewhat important & 0.03 & 0.001 & 0.3 & 0.003 \\
\hline & Very important & 0.02 & 0.001 & 0.2 & 0.001 \\
\hline A comfortable environment & Very important & 0.1 & 0.02 & 0.9 & 0.04 \\
\hline \multirow{2}{*}{ Absence of disease or injury } & Somewhat important & 0.03 & 0.001 & 0.3 & 0.003 \\
\hline & Very important & 0.001 & 0.001 & 0.05 & 0.0001 \\
\hline Control over their environment & Slightly important & 6 & 1.08 & 33.2 & 0.04 \\
\hline \multirow{3}{*}{ Opportunity to perform natural behaviours } & Neither important nor unimportant & 11.4 & 1.7 & 74.7 & 0.01 \\
\hline & Somewhat important & 7.7 & 1.2 & 51.3 & 0.03 \\
\hline & Very important & 9.4 & 1.4 & 64.2 & 0.02 \\
\hline \multirow[b]{2}{*}{ Absence of fear or distress } & Somewhat important & 0.1 & 0.03 & 0.6 & 0.01 \\
\hline & Very important & 0.08 & 0.02 & 0.4 & 0.001 \\
\hline \multicolumn{6}{|c|}{ Absence of Disease or Injury } \\
\hline Access to drinking water & Slightly important & 14.5 & 1.9 & 110.3 & 0.01 \\
\hline \multirow{4}{*}{ Space } & Slightly important & 0.04 & 0.001 & 0.9 & 0.05 \\
\hline & Neither important nor unimportant & 0.02 & 0.001 & 0.5 & 0.02 \\
\hline & Somewhat important & 0.002 & 0.001 & 0.6 & 0.02 \\
\hline & Very important & 0.01 & 0.001 & 0.3 & 0.009 \\
\hline Physical fitness & Very important & 0.03 & 0.001 & 0.3 & 0.003 \\
\hline Control over their environment & Very important & 0.2 & 0.005 & 0.8 & 0.03 \\
\hline \multirow{4}{*}{ Opportunity to perform natural behaviours } & Slightly important & 0.01 & 0.001 & 0.08 & 0.0001 \\
\hline & Neither important nor unimportant & 0.01 & 0.001 & 0.09 & 0.0001 \\
\hline & Somewhat important & 0.02 & 0.001 & 0.1 & 0.0001 \\
\hline & Very important & 0.02 & 0.001 & 0.05 & 0.0001 \\
\hline \multirow{4}{*}{ Absence of fear or distress } & Slightly important & 27.7 & 5.5 & 138.6 & 0.0001 \\
\hline & Neither important nor unimportant & 11 & 2.2 & 53.9 & 0.003 \\
\hline & Somewhat important & 13.6 & 2.7 & 68.6 & 0.002 \\
\hline & Very important & 8.5 & 1.6 & 43.8 & 0.01 \\
\hline \multirow{4}{*}{ Absence of pain } & Slightly important & 0.1 & 0.02 & 0.6 & 0.009 \\
\hline & Neither important nor unimportant & 0.07 & 0.01 & 0.4 & 0.002 \\
\hline & Somewhat important & 0.03 & 0.001 & 0.2 & 0.0001 \\
\hline & Very important & 0.01 & 0.001 & 0.08 & 0.0001 \\
\hline \multicolumn{6}{|c|}{ Control over Their Environment } \\
\hline Species-relevant nutrition & Very important & 0.2 & 0.06 & 0.6 & 0.007 \\
\hline \multirow{2}{*}{ Absence of disease or injury } & Somewhat important & 0.08 & 0.01 & 0.7 & 0.02 \\
\hline & Very important & 0.03 & 0.001 & 0.3 & 0.003 \\
\hline \multirow{2}{*}{ Opportunity to perform natural behaviours } & Somewhat important & 0.06 & 0.01 & 0.3 & 0.002 \\
\hline & Very important & 0.01 & 0.001 & 0.08 & 0.0002 \\
\hline \multirow{4}{*}{ Absence of fear or distress } & Slightly important & 0.2 & 0.05 & 0.8 & 0.02 \\
\hline & Neither important nor unimportant & 0.2 & 0.05 & 0.7 & 0.02 \\
\hline & Somewhat important & 0.1 & 0.04 & 0.6 & 0.009 \\
\hline & Very important & 0.1 & 0.03 & 0.5 & 0.004 \\
\hline \multirow{4}{*}{ Absence of pain } & Slightly important & 8.8 & 1.7 & 46.9 & 0.01 \\
\hline & Neither important nor unimportant & 8.3 & 1.6 & 44.1 & 0.01 \\
\hline & Somewhat important & 8.9 & 1.6 & 44.8 & 0.01 \\
\hline & Very important & 7.2 & 1.3 & 39.1 & 0.02 \\
\hline
\end{tabular}


Table A4. Cont.

\begin{tabular}{|c|c|c|c|c|c|}
\hline Opportunity to Perfo & al Behaviours & & & & \\
\hline \multirow{4}{*}{ Access to drinking water } & \multirow{4}{*}{$\begin{array}{l}\text { Slightly important } \\
\text { Neither important nor } \\
\text { unimportant } \\
\text { Somewhat important } \\
\text { Very important }\end{array}$} & 0.1 & 0.02 & 0.9 & 0.04 \\
\hline & & 0.1 & 0.01 & 0.8 & 0.03 \\
\hline & & 0.07 & 0.01 & 0.5 & 0.01 \\
\hline & & 0.03 & 0.001 & 0.3 & 0.002 \\
\hline \multirow{3}{*}{ A comfortable environment } & $\begin{array}{l}\text { Neither important nor } \\
\text { unimportant }\end{array}$ & 0.04 & 0.001 & 0.3 & 0.01 \\
\hline & Somewhat important & 0.02 & 0.001 & 0.1 & 0.0001 \\
\hline & Very important & 0.02 & 0.001 & 0.2 & 0.0001 \\
\hline \multirow{3}{*}{ Space } & $\begin{array}{l}\text { Neither important nor } \\
\text { unimportant }\end{array}$ & 37.0 & 1.5 & 915.6 & 0.03 \\
\hline & Somewhat important & 42.8 & 1.8 & 1023.4 & 0.02 \\
\hline & Very important & 53.3 & 2.1 & 1303.9 & 0.01 \\
\hline \multirow{4}{*}{ Physical fitness } & Slightly important & 0.01 & 0.001 & 0.1 & 0.0001 \\
\hline & $\begin{array}{l}\text { Neither important nor } \\
\text { unimportant }\end{array}$ & 0.01 & 0.001 & 0.07 & 0.0001 \\
\hline & Somewhat important & 0.01 & 0.001 & 0.1 & 0.0001 \\
\hline & Very important & 0.001 & 0.001 & 0.05 & 0.0001 \\
\hline \multirow{4}{*}{ Absence of disease or injury } & Slightly important & 12.7 & 1.03 & 156.1 & 0.05 \\
\hline & $\begin{array}{l}\text { Neither important nor } \\
\text { unimportant }\end{array}$ & 23.3 & 1.7 & 315.05 & 0.02 \\
\hline & Somewhat important & 24.3 & 1.7 & 337.6 & 0.02 \\
\hline & Very important & 15.4 & 1.1 & 214.3 & 0.04 \\
\hline Control over their environment & Slightly important & 7.7 & 0.1 & 0.03 & 0.7 \\
\hline $\begin{array}{l}\text { Opportunity to perform natural } \\
\text { behaviours }\end{array}$ & Very important & 0.08 & 0.01 & 0.6 & 0.01 \\
\hline \multirow{2}{*}{ Absence of pain } & Somewhat important & 0.02 & 0.001 & 0.09 & 0.0001 \\
\hline & Very important & 0.001 & 0.001 & 0.01 & 0.0001 \\
\hline \multicolumn{6}{|c|}{ Absence of Fear or Distress } \\
\hline \multirow{4}{*}{ Species-relevant nutrition } & Slightly important & 0.2 & 0.06 & 0.9 & 0.03 \\
\hline & $\begin{array}{l}\text { Neither important nor } \\
\text { unimportant }\end{array}$ & 0.1 & 0.04 & 0.5 & 0.001 \\
\hline & Somewhat important & 0.1 & 0.04 & 0.4 & 0.001 \\
\hline & Very important & 0.08 & 0.02 & 0.3 & 0.0001 \\
\hline \multirow{4}{*}{ Access to drinking water } & Slightly important & 34.07 & 3.6 & 322.7 & 0.002 \\
\hline & $\begin{array}{l}\text { Neither important nor } \\
\text { unimportant }\end{array}$ & 75.09 & 6.03 & 934.9 & 0.001 \\
\hline & Somewhat important & 84.6 & 6.6 & 1084.4 & 0.001 \\
\hline & Very important & 92.7 & 7.06 & 1271.09 & 0.001 \\
\hline Space & Slightly important & 0.02 & 0.001 & 0.4 & 0.01 \\
\hline \multirow{3}{*}{ Control over their environment } & Slightly important & 7.7 & 1.7 & 34.0 & 0.007 \\
\hline & Somewhat important & 0.1 & 0.03 & 0.4 & 0.001 \\
\hline & Very important & 0.03 & 0.01 & 0.1 & 0.0001 \\
\hline \multirow{2}{*}{ Absence of disease or injury } & Somewhat important & 0.2 & 0.05 & 0.9 & 0.04 \\
\hline & Very important & 0.07 & 0.02 & 0.3 & 0.001 \\
\hline \multirow{3}{*}{ Absence of pain } & $\begin{array}{l}\text { Neither important nor } \\
\text { unimportant }\end{array}$ & 0.1 & 0.02 & 0.6 & 0.01 \\
\hline & Somewhat important & 0.1 & 0.02 & 0.5 & 0.008 \\
\hline & Very important & 0.08 & 0.01 & 0.4 & 0.002 \\
\hline \multicolumn{6}{|c|}{ Absence of Pain } \\
\hline Species-relevant nutrition & Slightly important & 4.01 & 1.1 & 14.6 & 0.03 \\
\hline \multirow{4}{*}{ Space } & Slightly important & 0.03 & 0.001 & 0.9 & 0.04 \\
\hline & $\begin{array}{l}\text { Neither important nor } \\
\text { unimportant }\end{array}$ & 0.001 & 0.001 & 0.05 & 0.0001 \\
\hline & Somewhat important & 0.001 & 0.001 & 0.03 & 0.0001 \\
\hline & Very important & 0.001 & 0.001 & 0.02 & 0.0001 \\
\hline \multirow{3}{*}{ Absence of disease or injury } & $\begin{array}{l}\text { Neither important nor } \\
\text { unimportant }\end{array}$ & 0.07 & 0.1 & 0.8 & 0.03 \\
\hline & Somewhat important & 0.04 & 0.001 & 0.5 & 0.01 \\
\hline & Very important & 0.02 & 0.001 & 0.2 & 0.002 \\
\hline \multirow{3}{*}{ Absence of fear or distress } & $\begin{array}{l}\text { Neither important nor } \\
\text { unimportant }\end{array}$ & 0.07 & 0.02 & 0.3 & 0.0001 \\
\hline & Somewhat important & 0.001 & 0.001 & 0.01 & 0.0001 \\
\hline & Very important & 0.001 & 0.001 & 0.001 & 0.0001 \\
\hline
\end{tabular}




\section{References}

1. Lu, J.; Bayne, K.; Wang, J. Current status of animal welfare and animal rights in China. Altern. Lab. Anim. 2013, 41, 351-357. [CrossRef] [PubMed]

2. World Organisation for Animal Health. Terrestrial animal health code. In OIE International Standards; OIE: Paris, France, 2013.

3. Rowlands, M. Animal Rights: A Philosophical Defence; Macmillan Press: London, UK; St Martin's Press: New York, NY, USA, 1998.

4. Taylor, A. Animals and Ethics; Broadview Press: Peterborough, NE, Canada, 2009.

5. Eurobarometer. Attitudes of Europeans towards Animal Welfare; European Union: Maastricht, The Netherlands, 2016 ; Volume 26. [CrossRef]

6. Phillips, C. The Welfare of Animals: The Silent Majority; Springer: Berlin, Germany, 2009; Volume 8. [CrossRef]

7. Food and Agriculture Organization. FAOSTAT: Statistical Database. Available online: http://www.fao.org/faostat/en/\#data/QL (accessed on 19 June 2020).

8. FAO; IFAD; WFP. The State of Food Insecurity, The W. Strengthening the Enabling Environment for Food Security and Nutrition; FAO: Rome, Italy, 2014.

9. Sumner, L.W. Animal welfare and animal rights. J. Med. Philos. 1988, 13, 159-175. [CrossRef]

10. You, X.; Li, Y.; Zhang, M.; Yan, H.; Zhao, R. A survey of Chinese citizens' perceptions on farm animal welfare. PLoS ONE 2014, 9, e109177. [CrossRef]

11. Phillips, C.J.C. The Animal Trade; CAB International: Wallingford/Oxford, UK, 2015; Volume 208.

12. Zhigang, X. GM Rules Don't Block Imported Products; China Daily, Publicity Department of the Communist Party of China: Kunming, China, 2002.

13. Yan, Q.H.; Li, Y.B.; You, X.L.; Zhang, M.; Liu, Z.P.; Ge, Y. An investigation on social attitude on animal welfare in China. J. Nanjing Agric. Univ. 2013, 3, 99-105.

14. Wang, C.; Gu, H. Consumer's preference for animal welfare and other quality attributes. Manag. World 2014, 7, 67-82.

15. Li, P.J. Exponential growth, animal welfare, environmental and food safety impact: The case of China's livestock production. $J$. Agric. Environ. Ethics 2008, 22, 217-240. [CrossRef]

16. McOrist, S.; Khampee, K.; Guo, A. Modern pig farming in the Peoples's Republic of China: Growth and veterinary challenges. Rev. Sci. Tech. (Int. Off. Epizoot.) 2011, 30, 961-968. [CrossRef] [PubMed]

17. Anderson, B.D.; Ma, M.-J.; Wang, G.-L.; Bi, Z.-Q.; Lu, B.; Wang, X.-J.; Wang, C.-X.; Chen, S.-H.; Qian, Y.-H.; Song, S.-X.; et al. Prospective surveillance for influenza. Virus in Chinese swine farms. Emerg. Microbes Infect. 2018, 7, 87. [CrossRef] [PubMed]

18. Bedard, B.; Hunt, T. The emerging animal health delivery system in the People's Republic of China. Rev. Sci. Tech. (Int. Off. Epizoot.) 2004, 23, 297-304. [CrossRef] [PubMed]

19. Li, Y.; Wu, N.; Xu, R.; Li, L.; Zhou, W.; Zhou, X. Empirical analysis of pig welfare levels and their impact on pig breeding efficiency-Based on 773 pig farmers' survey data. PLOS ONE 2017, 12, e0190108. [CrossRef]

20. Sinclair, M.; Fryer, C.; Phillips, C.J.C. The benefits of improving animal welfare from the perspective of livestock stakeholders across Asia. Animals 2019, 9, 123. [CrossRef] [PubMed]

21. Rushen, J.; Haley, D.; De Passillé, A. Effect of softer flooring in tie stalls on resting behavior and leg injuries of lactating cows. J. Dairy Sci. 2007, 90, 3647-3651. [CrossRef] [PubMed]

22. Platto, S.; Zhu, Q.; Guo, A.; He, Q.; Hu, S.; Valros, A.; Irwin, A. Chinese farmers' attitude towards the improvement of animal welfare in their facilities. Anim. Welf. 2020, 29, 99-112. [CrossRef]

23. Sinclair, M.; Phillips, C.J.C. The cross-cultural importance of animal protection and other world social issues. J. Agric. Environ. Ethics 2017, 30, 439-455. [CrossRef]

24. Phillips, C.; Izmirli, S.; Aldavood, S.J.; Alonso, M.E.; Choe, B.; Hanlon, A.; Handziska, A.; Illmann, G.; Keeling, L.J.; Kennedy, M.; et al. An international comparison of female and male students' attitudes to the use of animals. Animals 2011, 1, 7-26. [CrossRef] [PubMed]

25. Sinclair, M.; Phillips, C.J.C. Key tenets of operational success in international animal welfare initiatives. Animals 2018, 8, 92. [CrossRef] [PubMed]

26. Phillips, C.; Izmirli, S.; Aldavood, S.; Alonso, M.; Choe, B.; Hanlon, A.; Handziska, A.; Illmann, G.; Keeling, L.; Kennedy, M.; et al. Students' attitudes to animal welfare and rights in Europe and Asia. Anim. Welf. 2012, 21, 87-100. [CrossRef]

27. Pifer, R.; Shimizu, K.; Pifer, L. Public attitudes toward animal research: Some international comparisons. Soc. Anim. 1994, 2 , 95-113. [CrossRef] [PubMed]

28. Brambell, F.W.R. Report of the Technical Committee to Enquire into the Welfare of Animals Kept under Intensive Livestock Husbandry Systems; Her Majesty's Stationery Office: London, UK, 1965.

29. The Bing, GeoNames Geographical Database, Microsoft. Available online: https://www.geonames.org/4061113/excel.html (accessed on 19 June 2019).

30. China, National Bureau of Statistics of China Statistical Yearbook. Available online: http://www.stats.gov.cn/ (accessed on 19 June 2019).

31. Global Religious Futures. Global Religious Futures. Available online: http://www.globalreligiousfutures.org/ (accessed on 19 June 2019). 
32. Heleski, C.R.; Mertig, A.G.; Zanella, A.J. Results of a national survey of US veterinary college faculty regarding attitudes toward farm animal welfare. J. Am. Vet. Med. Assoc. 2005, 226, 1538-1546. [CrossRef]

33. Paul, E.S.; Podberscek, A.L. Veterinary education and students' attitudes towards animal welfare. Vet. Rec. 2000, 146, 269-272. [CrossRef]

34. Hepper, P.G.; Wells, D.L. Pet ownership and adults' views on the use of animals. Soc. Anim. 1997, 5, 45-63. [CrossRef]

35. Nøhr, R.; Lund, T.B.; Forkman, B.; Sandøe, P. How Do Different Kinds of Animal Experts View and Weigh Animal Welfare Indicators? Report-Institute of Food and Resource Economics, Department of Food and Resource Economics; University of Copenhagen, Statens Jordbrugsog Fiskeriøkonomiske Institute: Copenhagen, Denmark, 2016.

36. Bracke, M.B.; Edwards, S.A.; Engel, B.; Buist, W.G.; Algers, B. Expert opinion as 'validation' of risk assessment applied to calf welfare. Acta Vet. Scand. 2008, 50, 29. [CrossRef] [PubMed]

37. Ortega, D.L.; Wang, H.H.; Eales, J.S. Meat demand in China. China Agric. Econ. Rev. 2009, 1, 410-419. [CrossRef]

38. Shi, T. Ecological agriculture in China: Bridging the gap between rhetoric and practice of sustainability. Ecol. Econ. 2002, 42, 359-368. [CrossRef]

39. Mendez, M.A.; Popkin, B.M. Globalization, urbanization and nutritional change in the developing world. J. Agric. Dev. Econ. 2004, 1, 220-241.

40. Roex, J.; Miele, M. Farm Animal Welfare Concerns. In Consumers, Retailers and Producers; Welfare Quality Project Report; Welfare Quality: Uppsala, Sweden, 2005.

41. Moran, D.; McVittie, A. Estimation of the value the public places on regulations to improve broiler welfare. Anim. Welf. 2008, 17, 43-52.

42. Bozzo, G.; Barrasso, R.; Grimaldi, C.A.; Tantillo, G.; Roma, R. Consumer attitudes towards animal welfare and their willingness to pay. Vet. Ital. 2019, 55, 1823.

43. Davey, G.; Wu, Z. Attitudes in China toward the use of animals in laboratory research. Altern. Lab. Anim. 2007, 35, 313-316. [CrossRef] [PubMed]

44. Yang, D.; Dai, X.; Deng, Y.; Lu, W.; Jiang, Z. Changes in attitudes toward wildlife and wildlife meats in Hunan Province, central China, before and after the severe acute respiratory syndrome outbreak. Integr. Zool. 2007, 2, 19-25. [CrossRef] [PubMed]

45. McEachern, M.G.; Schroder, M.J.; Willock, J.; Whitelock, J.; Mason, R. Exploring ethical brand extensions and consumer buying behaviour: The RSPCA and the "Freedom Food" brand. J. Prod. Brand Manag. 2007, 16, 168-177. [CrossRef]

46. Bonner, J. Welfare issues. BSAVA Companion 2017, 2017, 10-11. [CrossRef]

47. Sinclair, M.; Zhang, Y.; Descovich, K.; Phillips, C.J. Farm animal welfare science in China-A bibliometric review of Chinese literature. Animals 2020, 10, 540. [CrossRef] [PubMed]

48. Harper, G.; Henson, S. Consumer Concerns about Animal Welfare and the Impact on Food Choice, Final Report EU FAIR CT98-3678; Centre for Food Economics Research (CeFER) Department of Agricultural and Food Economics: Reading, UK, December 2001; Available online: https:/ / ec.europa.eu/food/sites/food/files/animals/docs/aw_arch_hist_eu_fair_project_en.pdf (accessed on 30 June 2019).

49. Phillips, C.J.C.; McCulloch, S. Student attitudes on animal sentience and use of animals in society. J. Biol. Educ. 2005, 40, 17-24. [CrossRef] 